\title{
Explaining the leopards' spots: Responsibility-embedding in business model artefacts across spaces of institutional complexity
}

DOI:

10.1016/j.Irp.2019.101891

\section{Document Version}

Accepted author manuscript

Link to publication record in Manchester Research Explorer

Citation for published version (APA):

Laasch, O., \& Pinkse, J. (2019). Explaining the leopards' spots: Responsibility-embedding in business model artefacts across spaces of institutional complexity. Long Range Planning, 53(4), [101891]. https://doi.org/10.1016/j.lrp.2019.101891

\section{Published in:}

Long Range Planning

\section{Citing this paper}

Please note that where the full-text provided on Manchester Research Explorer is the Author Accepted Manuscript or Proof version this may differ from the final Published version. If citing, it is advised that you check and use the publisher's definitive version.

\section{General rights}

Copyright and moral rights for the publications made accessible in the Research Explorer are retained by the authors and/or other copyright owners and it is a condition of accessing publications that users recognise and abide by the legal requirements associated with these rights.

\section{Takedown policy}

If you believe that this document breaches copyright please refer to the University of Manchester's Takedown Procedures [http://man.ac.uk/04Y6Bo] or contact uml.scholarlycommunications@manchester.ac.uk providing relevant details, so we can investigate your claim.

\section{OPEN ACCESS}




\title{
Explaining the Leopards' Spots: Responsibility-Embedding in Business Model Artefacts across Spaces of Institutional Complexity
}

\author{
Oliver Laasch \\ -corresponding author- \\ (oliver.laasch@,nottingham.edu.cn) \\ University of Nottingham, Ningbo China Campus, \\ 199 Taikang E Rd, Yinzhou, Ningbo, Zhejiang, China, 315100
}

Jonatan Pinkse

(jonatan.pinkse@manchester.ac.uk)

The University of Manchester, Denmark Road Building, Denmark Road, Manchester M13 9NG, UK

\section{Acknowledgements}

The authors would like to acknowledge generous funding in the form of a Marie Curie Research Fellowship awarded by the European Commission, which has made this research possible. Previous versions of this article have greatly benefitted from kind feedback provided by Paul Dewick, Irene Henriques, Philippe Laredo, Sally Randles, Andreas Rasche, Ramona Rauter, Nigel Roome, Wendy Smith, by four anonymous reviewers at Long Range Planning, and by the associate editor CharlesClemens Rüling. 


\title{
Explaining the Leopards' Spots: Responsibility-Embedding in Business Model Artefacts across Spaces of Institutional Complexity
}

\begin{abstract}
This article explores the phenomenon that corporations' commercial-logic business models increasingly embed responsibility-logic patterns: The proverbial leopards' spots. We have conducted a thematic analysis of responsibility patterns in annual report business model descriptions (artefacts) and a qualitative comparative analysis of corporations' strategic environment. We find distinct responsibility patterns, uniquely combined in four distinct types of responsibility business model artefacts. We explain these types through responses to institutional complexity between commercial and responsibility logics. Strategic responses were enabled or constrained by the characteristics of the varying spaces of institutional complexity of particular corporations. We contribute to an emerging heterogeneous business model literature by providing empirical evidence. We contribute to the institutional discussion of corporate responsibility by providing a typology of responsibility business models and by explaining why each type emerged in their respective institutional space. We also discuss how practitioners' efforts to embed responsibility into their business models may benefit from our findings.
\end{abstract}

Keywords: corporate responsibility, corporate sustainability, heterogeneous business models, institutional complexity, institutional logics 


\section{INTRODUCTION}

'Our Business Model ... is to harness our ... heritage as a leader in sustainability and our scale and sourcing capability ... we generate value for our people, communities and shareholders.' (Kingfisher, Annual Report 2014)

The discussion of organizational hybridity has emphasized social enterprises and not-for-profit organizations (Battilana \& Lee, 2014; Jay, 2013; Mair et al., 2015; Ometto et al., 2018; Pache \& Santos, 2013), where less prominent commercial elements are integrated into structures dominated by a social responsibility logic (Alter, 2007; Pache \& Santos, 2010; Stevens et al., 2015). We know much less about the counterpart where for-profit companies integrate responsibility elements into dominant commercial structures, even though hybridity in 'corporations that engage in CSR' has been presented as an important area for future research (Battilana \& Lee, 2014, p. 425). In contrast, the business model literature has theorized that multiple logics—e.g. commercial and responsibility logics — can shape hybrid business models (Laasch, 2018b; Ocasio \& Radoynovska, 2016), but it has not yet provided empirical evidence for this claim. This paper aims to address both gaps by empirically exploring the hybridity of for-profit corporations' business models where responsibilitylogic elements are embedded into commercial-logic structures. With reporting standards' pressures to include both business models and corporate responsibility into annual reports, a better understanding of their integration will also be of high relevance to management practitioners.

As the above quote of the FTSE100-listed do-it-yourself retailer Kingfisher shows, the company applies this form of hybridity in its business model description which embeds responsibility elements (e.g. 'communities', 'leader in sustainability') into commercial business-model structures (e.g. 'scale', 'sourcing capability', 'shareholders'). Such business model descriptions-our paper's unit-of-analysis - have been conceptualized as business model artefacts (Chesbrough \& Rosenbloom, 2002; Demil \& Lecocq, 2015; Doganova \& Eyquem-Renault, 2009): manifestations of the business model which can take material (e.g. products, core technologies) or visual-textual form (e.g. business plans, power point presentations) (Havemo, 2018). Looking at other business model artefacts in the annual reports of FTSE100 corporations, an intriguing variety appears in the embedding of 
responsibility elements across the business model functions of value proposition, creation, exchange, and capture. Kingfisher's embedding focuses on sustainable triple bottom line value capture and becoming 'Net Positive'. The bank Barclays communicates the social value proposition of 'making Britain prosper' to be achieved through 'sustainable value creation', while mining company Fresnillo claims to benefit stakeholders through value exchange with their communities, based on 'access, trust, [and] respect'. In contrast, similar companies in the same industries-e.g. Royal Bank of Scotland and Glencore — do not embed responsibility into their business model artefacts. This variety in embedding and non-embedding of responsibility seems surprising. If the FTSE100 were simply doing 'more' responsibility-embedding in response to the heightened institutional demand, we would expect to see isomorphism towards one way of embedding responsibility, but this is not the case.

Then again, the business model artefacts mentioned do not have a plain commercial logic either, but one that is 'spotted' with patterns of responsibility elements. The fable How the Leopard Got Its Spots by Rudyard Kipling describes a strikingly similar story. The originally plain-coloured Leopard camouflages into its variegated environment by developing spots. The story resembles a core narrative of organizational institutionalism where organizations aim to blend into their complex institutional spaces (Deephouse \& Suchman, 2008; Suchman, 1995). To gain legitimacy, they 'blend in' by responding to multiple, complex institutional logics (Dunn \& Jones, 2010; Greenwood et al., 2011; Kraatz \& Block, 2008; Thornton \& Ocasio, 1999). Responses to complex institutional logics are increasingly likely to materialize in business models (Ocasio \& Radoynovska, 2016; Stål \& Corvellec, 2018). Traditionally, companies' business models exclusively embodied a commercial logic (Doganova \& Eyquem-Renault, 2009; Johnson et al., 2008; Zott \& Amit, 2008), but we now also see alternative business models that embed elements from various non-commercial logics (Arend, 2013; Laasch, 2018a, 2018b; Randles \& Laasch, 2016; Spieth et al., 2018). Responsibility is such an alternative logic that increasingly shapes business models (Aharonson \& Bort, 2015; Meyer \& Höllerer, 2016; Naqvi, 2015; Raynard et al., 2013; Testa et al., 2015; Westermann-Behaylo et al., 2013).

In this paper, we seek to address two questions: 1) What distinct types of responsibilityembedding can we observe in the business model artefacts of the FTSE100 and 2) why are there 
varieties of responsibility-embedding in business model artefacts? Staying within our analogy, we would thus like to understand what kind of spots the leopards got and why? To address these questions, we will empirically explore the patterns of responsibility-embedding across FTSE100listed companies' value proposition, creation, exchange, and capture and explain the emerging patterns of responsibility-embedding by conceptualizing them as a strategic response across distinct spaces of institutional complexity. To frame our analysis conceptually, we bring together two literatures in the context of strategy and business models (Casadesus-Masanell \& Ricart, 2010; Massa et al., 2017; Teece, 2010). First, we build on the literature on strategic responses to complex institutional logics (Greenwood et al., 2011; Pache \& Santos, 2010; Vermeulen et al., 2014) which argues that such complexity can lead to a combination of elements from multiple institutional logics in heterogeneous arrangements (Battilana \& Lee, 2014; Jay, 2013; Pache \& Santos, 2013; Raynard, 2016). Secondly, we draw on the literature that conceptualizes business models as heterogeneous organizational value logics (Laasch, 2018b; Ocasio \& Radoynovska, 2016; Smith et al., 2010; Snihur \& Tarzijan, 2018; Spieth et al., 2018) and contends that business models combine elements related to a variety of institutional logics across the value proposition, creation, exchange and capture (Casadesus-Masanell \& Ricart, 2010; Chesbrough \& Rosenbloom, 2002; Teece, 2010; Zott \& Amit, 2010).

By identifying distinct patterns in the embedding of responsibility into companies' business model artefacts, we contribute to the emerging literature on heterogeneous business models (e.g. Laasch, 2018b; Ocasio \& Radoynovska, 2016). We provide empirical evidence for this so far theoretical discussion. We also contribute to the literatures on strategic responses to institutional complexity (Bertels \& Lawrence, 2016; Misangyi, 2016; Smith \& Tracey, 2016) and institutional perspectives on corporate responsibility (Meyer \& Höllerer, 2016; Stål \& Corvellec, 2018; Yin et al., 2016). We explain why there are distinct patterns in responsibility-embedding across business model artefacts. In addition, we extend the discussion of organizational hybridity, which was limited to the study of social enterprises (Battilana \& Lee, 2014; Jay, 2013; Raynard, 2016), to the context of corporate responsibility. Finally, we offer a framework for practitioners to explore in what ways responsibility can be embedded into business models. 
In the next sections, we first build a conceptual basis for our empirical work by reviewing the literatures of heterogeneous business models and how these relate to institutional aspects of the strategic environment. We then introduce our three-step research design and present the findings through an explanatory typology of responsibility-embedded business models. We close the paper with a discussion of future research and practitioner implications.

\section{HETEROGENEOUS BUSINESS MODELS FROM EMBEDDING RESPONSIBILITY}

Business models and strategy are intertwined (Casadesus-Masanell \& Ricart, 2010; Ocasio \& Radoynovska, 2016; Ritter \& Lettl, 2018; Teece, 2010; Zott \& Amit, 2008, 2013). However, while strategy is mainly focused on value capture and how companies achieve competitive advantage, business models draw more attention to value creation (Abdelkafi \& Täuscher, 2016; Bohnsack et al., 2014; Chesbrough \& Rosenbloom, 2002; Johnson et al., 2008; Zott et al., 2011). According to Massa et al. (2017), a major stream of business model research focuses on the demand side: the influence customers and other stakeholders in the strategic environment have on business models. McGrath (2010) suggests that business models adjust through experimentation and learning in interaction with the strategic environment. The business model starts as a 'hypothesis' of what strategic stakeholders want (Teece, 2010), which is only realized through trial and error learning in interaction with the strategic environment (Sosna et al., 2010), thus making them reflections of a firm's realized strategy (Casadesus-Masanell \& Ricart, 2010). Demil et al. (2018) argue, therefore, that a business model reflects a continuous co-evolution with the strategic environment. In this paper, we focus on institutional aspects of business models' strategic environment through the notion of 'institutional spaces', as we will explain further below.

\section{Heterogeneous Business Models and Value Functions}

Business models are commonly understood as commercial value logics of businesses (Abdelkafi \& Täuscher, 2016; Casadesus-Masanell \& Ricart, 2010; Chesbrough \& Rosenbloom, 2002; Johnson et al., 2008; Teece, 2010; Zott et al., 2011). For instance, Netflix's commercial value logic consists of a high-end entertainment value proposition; relying on value creation of original series, movies, and documentaries; value exchange through providing online access; and value 
capture in the form of subscription fees. However, business models may also integrate elements from alternative, non-commercial logics (Arend, 2013; Laasch, 2018a, 2018b; Ocasio \& Radoynovska, 2016; Spieth et al., 2018), including welfare logics in social enterprises (Darby \& Jenkins, 2006; Seelos \& Mair, 2005; Seelos \& Mair, 2007) and the logic of sustainable development in corporate sustainability (Bocken et al., 2014; Boons \& Lüdeke-Freund, 2013; Stubbs \& Cocklin, 2008). This integration leads to heterogeneous business models where elements from plural institutional logics are combined (Laasch, 2018b; Ocasio \& Radoynovska, 2016). For instance, Greyston Bakery relies on a social welfare logic in value creation, organizing their bakery around inclusive employment for the chronically unemployed. Yet, they also have a commercial-logic value proposition of high-quality bakery products that appeals to customers like Unilever and Delta Airlines.

Elements from non-commercial logics may become embedded across all business model functions of value proposition, creation, exchange, and capture (Chesbrough \& Rosenbloom, 2002; Osterwalder, 2004; Richardson, 2008; Teece, 2010; Zott et al., 2011). If well aligned, these functions create a coherent narrative of the type of value a company proposes, how it is created, exchanged and captured (George \& Bock, 2011; Lund, 2013; Magretta, 2002). We will briefly introduce each function and exemplify how they relate to responsibility.

The value proposition function matches a company's resources and aspirations with the external demands, needs and wants (Osterwalder et al., 2014). The value proposition has been conceptualized narrowly as directed towards customers and related to value in companies' products and services (Johnson et al., 2008). A broader conceptualization understands the value proposition to be directed at company stakeholders as a whole (Frow \& Payne, 2011), implying a variety of different types of value demanded and proposed (Emerson, 2003). For instance, Bohnsack and Pinkse (2017) study how car manufacturing companies reorganized value propositions to respond to demands for environmentally responsible mobility.

Value creation includes what is required to realize the value proposed, including employees, processes, resources and structures (Johnson et al., 2008; Osterwalder \& Pigneur, 2010). A broad conception of value creation involves activities between a variety of partners inside and outside company boundaries, who may also be recipients of value (Nenonen \& Storbacka, 2010). Laasch 
(2018a) shows, for example, how a global food retailer changed its business model by linking their responsibility programme to various value creation activities, including healthy product formulation and eco-efficient infrastructure management, while relying different external partners, such as NGOs, governmental agencies, and local communities.

Given the networked nature of business models, value exchange (Gordijn et al., 2000; Osterwalder, 2004) between a variety of stakeholders, both partners and final recipients of value created (Richardson, 2008), is another key function of value logics. A narrow conception refers to value delivery, implying a uni-directional value-chain-like delivery from supplier to company and customer, respectively (Osterwalder, 2004). In the broader conceptualization, the value created is exchanged multi-directionally in networks where the same entity can both be producer and consumer of value (Breuer \& Lüdeke-Freund, 2017). Bocken et al. (2016) illustrate how to organize value exchange in and between business models to create circular exchange of environmental resources to further environmental sustainability.

Value capture narrowly refers to how much of the value a company creates, it can keep (Bowman \& Ambrosini, 2000; Chesbrough \& Rosenbloom, 2002). It relates value capture to a company's immediate financial performance (Zott \& Amit, 2008), particularly the profit formula as

well as reporting and control systems (Johnson et al., 2008). A broader understanding looks for value capture and impacts in a variety of locations inside and outside the organization, including positive and negative impacts, value created and destroyed (Roome \& Louche, 2016). It relates to the achievement of social, environmental and economic goals in the medium and long run (Breuer \& Lüdeke-Freund, 2015; Osterwalder \& Pigneur, 2010; Randles \& Laasch, 2016). Roome and Louche (2016) studied, for example, how a textile and a construction company innovated their business model to reduce the environmental value destroyed.

\section{Business Model Artefacts Forged in Spaces of Institutional Complexity}

The value logics of business models frequently materialize in business model artefacts (Chesbrough \& Rosenbloom, 2002; Demil \& Lecocq, 2015; Doganova \& Eyquem-Renault, 2009), which, as mentioned, can be of material or visual-textual form (Havemo, 2018). Business model 
artefacts take part in the strategizing processes shaping value logics and in the enactment of these logics as activity systems (Comi \& Whyte, 2018; Gond et al., 2017; Knight et al., 2018; Laasch, 2016, 2018a; Zott \& Amit, 2010). Hence, business model artefacts both influence and (imperfectly) express value logics (Laasch, 2016, 2018a). ${ }^{1}$ For instance, business model artefacts in annual reports are (imperfect) expressions of a company's enacted value logic and an aspirational expression of the company's ideal value logic.

In institutionally complex spaces (Greenwood et al., 2011; Scott \& Meyer, 1994), business model artefacts can serve as 'integrative devices' that combine demands from the multiple logics existing in the space (Raynard, 2016, p. 22). In the context of this paper, we focus on institutional spaces' distinct legitimacy pressures for corporate responsibility (Aguilera et al., 2007), due to distinct compositions of salient stakeholders in each space (Ioannou \& Serafeim, 2015; Khurram \& Petit, 2017; Mitchell et al., 2011), resulting in distinct demands for commercial and responsibility logic elements. For instance, a traditional investment firm is likely to operate in an institutional space with salient stakeholders that primarily have commercial logic demands, including profit-demanding investors, funding-seeking investees, and economic stability-demanding regulators (Ioannou \& Serafeim, 2015). In contrast, a work integration social enterprise's institutional space is likely to be characterized by salient responsibility-logic stakeholders such as collaborating not-for-profit organizations, public social services agencies, as well as networks of social-purpose-driven individual supporters, and beneficiaries (Pache \& Santos, 2013). When the institutional space exerts pressure to follow different logics simultaneously (Bertels \& Lawrence, 2016; Misangyi, 2016; Vermeulen et al., 2014), business model artefacts can become part of the sensemaking process to combine these logics (Hahn et al., 2014; Meyer \& Höllerer, 2016; Schultz \& Wehmeier, 2010). Accordingly, in response to demands in the institutional space, companies start embedding responsibility into their business model artefacts which materializes in an increasing 'responsibilization' (Banerjee, 2011; Grayson, 2011;

\footnotetext{
${ }^{1}$ However, this does not mean that business model artefacts perfectly correspond to companies' enactment or to underlying logics. These distinct manifestations of business models exist in a dynamic entanglement leading to their continuous shapeshifting and mutual readjustment (Laasch, 2016, 2018a).
} 
Shamir, 2008; Short et al., 2013) of commercial business models (Laasch, 2018a; Stål \& Corvellec, 2018).

The conditions of institutional complexity which influence strategic decisions that shape business model artefacts vary across institutional spaces, each with distinct combinations and intensities of institutional logics (e.g. Ometto et al., 2018). Institutional spaces have been understood as demarcated by national boundaries (Gaur et al., 2007; Kostova \& Zaheer, 1999; Manolova et al., 2008); as the institutional conditions of organizational fields demarcated by membership, social dynamics and organizational characteristics (Cooney, 2006; Lawrence \& Phillips, 2004; Leibel et al., 2018; Purdy \& Gray, 2009; Suddaby \& Viale, 2011; Zietsma \& Lawrence, 2010); and as spaces 'inbetween', demarcated by the boundaries of other spaces they are outside of, for instance, interstitial spaces between fields (Martin, 2008; Misangyi, 2016).

\section{Connecting Conceptual Frame and Research Questions}

We can now connect the conceptual development to our research questions. Our conceptual development has yielded a conceptual frame in which strategic responses to institutional complexity (Greenwood et al., 2011; Meyer \& Höllerer, 2016; Ocasio \& Radoynovska, 2016) across distinct institutional spaces (Martin, 2008; Misangyi, 2016; Ometto et al., 2018) shape business model artefacts (Laasch, 2018a; Raynard, 2016; Smith et al., 2010). Artefacts' value proposition, creation, exchange and capture thus combine elements from multiple institutional logics beyond the received commercial one (Laasch, 2018b; Ocasio \& Radoynovska, 2016). Our first question—“"What distinct types of responsibility-embedding can we observe in the business model artefacts of the FTSE100?"-refers to the conceptual insight that responsibility logics may occur across business model artefacts' value proposition, creation, exchange, and capture. Our second question-“'Why are there varieties of responsibility-embedding in business model artefacts?"- builds up on this conceptual frame as it assumes that distinct conditions of institutional complexity in the institutional spaces that corporations inhabit can explain the variety in responsibility-embedding. 


\section{METHODS: CONTEXT, SAMPLE AND ANALYSES}

We seek to address our research questions, firstly, by analyzing the business model artefacts in the 2014 annual reports of the 100 most valuable corporations at the London Stock Exchange (FTSE100). The artefacts included a dedicated section typically titled "business model", 2-4 pages long, containing both textual and visual elements. Ninety-five of the FTSE100 provided such business model artefacts. Secondly, we studied each corporation's distinct institutional space by reviewing non-business-model report sections, describing institutional factors in the strategic environment, and reviewed secondary third-party material for triangulation. The FTSE100 were sampled purposively for their relevant empirical material on responsibility-embedding in business model artefacts. FTSE100 included both companies like Unilever, often discussed as a responsibility leader, and controversial companies like BP. Both groups were likely to show responses to responsibility logics. The initial rationale for selecting the FTSE100 was a timely opportunity in this unique, novel source of data: The FTSE reporting requirements had changed in 2013, to include the business model (FRC, 2012, p. 21).

Figure 1 summarizes the three steps of our research design. In the first step, we conducted a thematic analysis to identify the responsibility patterns in the value proposition, creation, exchange and capture. In the second step, we tried to explain why there are distinct responsibility businessmodel types. We conducted a qualitative comparative analysis to cluster companies into different types, based on characteristics of each company's institutional space and responsibility-embedding. In the third step, we joined the first two analyses by identifying each type's unique responsibility patterns through an intensity analysis showing which patterns of embedding were prominent in each business-model type. The overall analysis was conducted by two coders to increase rigor. The first coder engaged in the main coding in each round. The second coder stress-tested codes and identified additional observations. We now provide further detail for each step of the analysis. 


\section{Step 1: Thematic Analysis $\rightarrow$ Responsibility Patterns}

To identify patterns of responsibility-embedding across FTSE100 business models, we used a thematic analysis of companies' responsibility elements embedded in their business model artefacts (Braun \& Clarke, 2006; King \& Brooks, 2017; Vaismoradi et al., 2013). Thematic analyses cluster similar instances of codes to themes to reveal patterns in empirical material (Boyatzis, 1998). In our analysis, the themes express distinct patterns of responsibility-embedding. This first step consisted of three coding rounds (Aronson, 1995; Fereday \& Muir-Cochrane, 2006; Pehlke et al., 2009).

In the first round, we used line-by-line coding (Glaser \& Strauss, 2012 [1967]; Saldaña, 2012) to identify responsibility-related text segments in business model artefacts, associating distinct vocabularies with distinct institutional logics (Cornelissen et al., 2015; Jones \& Livne-Tarandach; Loewenstein et al., 2012; Misangyi, 2016; Ocasio et al., 2015). For instance, Johnson Matthey stated 'our business model is to ... optimise the use of natural resources and enhance quality of life.' Vocabularies of 'natural resources' and 'quality of life' in this text segment were associated with the responsibility logic, oriented by extant literature describing such a logic (e.g. Jamali \& Hossary, 2019; Meyer \& Höllerer, 2016). This identification applied an integrative understanding, including all business model elements related to responsibility, sustainability, and ethics (Laasch \& Conaway, 2015; Laasch \& Moosmayer, 2015; Montiel, 2008; Schwartz \& Carroll, 2008; Setó-Pamies \& Papaoikonomou, 2015; Van Marrewijk, 2003), such as BAE Group's 'responsible behavior', Astra Zeneca's 'sustainable healthcare', and GKN's 'ethical business practices'.

In the second round, we used the definitions of the value proposition, creation, exchange and capture to deductively allocate all text segments from the first round in one of these business model functions. For instance, Anglo American described the business model as 'operating safely and responsibly across the mining value chain', which was allocated under value creation, due to its description of operational aspects of value creation.

In the third round, we inductively identified patterns of the responsibility logic (Reay \& Jones, 2016). For each business model function, similar responsibility-embedding codes were 
clustered into main patterns and more abstract sub-patterns (Gioia et al., 2012). For instance, 'contributing to the development of the communities in which we operate, via (...) partnering' (Astra Zeneca) and 'to work together with our regulators to de-risk the industry' (Barclays) were clustered under the main pattern of Cocreation and Partnership.

\section{Step 2: Qualitative Comparative Analysis $\rightarrow$ BM Types across Institutional Spaces}

In Step 2, we developed a framework explaining distinct types of responsibility business models across distinct institutional spaces using qualitative comparative analysis (Livne-Tarandach et al., 2015; Rihoux \& Lobe, 2009) to distinguish configurations of business models (Aversa et al., 2015; Täuscher, 2017). FTSE100 business models were clustered into sets with distinct characteristics (Ragin, 2008; Rihoux \& Lobe, 2009) based on a systematic comparison through bivariate analysis (Lieberman, 2005). We used three bivariate qualitative criteria derived from the literature on responsibility-embedding to provide us with insights into the influence of the institutional space on responsibility-embedding (see classification Table A. 1 in the appendix). First, from companies' industry classifications we distinguished each corporation's sector as B2B or B2C. While B2C brands mainly respond to responsibility-logic demands for brand protection (e.g. Chapple \& Moon, 2005; Minor \& Morgan, 2011; Werther \& Chandler, 2005), B2Bs are mostly embedded in a commercial logic shared by their sector partners (e.g. Blenkhorn \& MacKenzie, 2017; Leppelt et al., 2013).

Second, we distinguished between high scrutiny (due to industry scrutiny/company scandal) and low scrutiny. This distinction is based on the assumption that industry scrutiny (e.g. mining's reputation to be dangerous and dirty) and individual company scandals (e.g. Tesco's horsemeat scandal) imply increased responsibility-logic demands in the company's institutional space (e.g. Kubenka \& Myskova, 2099; Popa \& Salanta, 2014; Yoon et al., 2006). To identify industry scrutiny and company scandals, we used three types of empirical material. First, we screened companies' 2014 strategic reports' sections describing the strategic environment (e.g. Tesco's section titled "Economic Environment") for indications of industry scrutiny or further scandals. We did so too with Chief Executives' introductions of reports, describing context and motivations for decision-making. Although in the same document, these sections provide contents distinct from the business model 
sections. They present context and antecedents of strategic responses, including those related to the business model. We also screened corporate social responsibility reports for the period 2011-2013. The three-year period was chosen based on the assumption that scandals would need to be recent in public memory to lead to greater scrutiny. Given the materiality principle such reports are bound to address scandals and issues with social, environmental, and ethical relevance. ${ }^{2}$ Finally, we triangulated by conducting a broader web search. This search included Google News searches with keywords being the respective company name + scandal, issue, controversy, or scrutiny as well as a review of the company's Wikipedia page, which typically has a section titled "criticism" or "controversies". 3

Third, building on Step 1 of our analysis, we used annual reports' business model sections to distinguish between business models which embedded responsibility and those which did not. We used the responsibility pattern of an integrated corporate responsibility programme as a characteristic to distinguish a 'signalling' response to responsibility demands from a 'conforming' response (Berry \& Rondinelli, 1998; Groza et al., 2011; Torugsa et al., 2012). The clustering led to six sets (types) of business models each with distinct combinations of institutional spaces and strategic responses to embed responsibility, or not.

\section{Step 3: Intensity Analysis $\rightarrow$ Responsibility Embedding Patterns of Types}

In the final step, we juxtaposed the responsibility patterns of Step 1 with the types of responsibility business models that emerged in Step 2. We used the NVivo matrix query function to identify how frequently each embedding pattern occurred on average for each type of responsibility business model artefact. In this way, we identified unique responsibility-embedding patterns for each business model type. This final step of the analysis served two purposes. Firstly, it provides a description of the unique responsibility-embedding patterns that constitute each responsibility business model type. Secondly, if these empirically observed patterns were consistent with the types of strategic response suggested by our framework, these "observable implications" (King et al., 1994,

\footnotetext{
${ }^{2}$ See https://www.globalreporting.org/standards/questions-and-feedback/materiality-and-topic-boundary/

${ }^{3}$ See e.g. https://en.wikipedia.org/wiki/Tesco\#Criticism
} 
p. 28) would serve to corroborate the framework's explanation of distinct types of responsibility business models, strategically (cor)responding to each corporation's space of institutional complexity.

\section{EXPLAINING VARIETIES OF RESPONSIBILITY-EMBEDDING IN BUSINESS MODELS}

Findings of this paper consist of three main sections. Together they address our objective to explain the variety of responsibility-embedding into FTSE100 corporations' business model artefacts. Addressing the first research question, we identify patterns of responsibility-embedding across business model functions. Addressing the second question, we explain four types of responsibility business models and two types of regular commercial business models through distinct responses in spaces of institutional complexity and show how unique combinations of embedding patterns distinguished the responsibility business model types.

\section{Responsibility-Embedding Patterns}

Figure 2 shows patterns of responsibility-embedding across the value proposition, creation, exchange, and capture functions. We distinguish between main patterns and sub-patterns. These patterns of responsibility-embedding provide an overview of the variety of responsibility logic elements embedded into commercial business model artefacts, across business model functions. This description primes our later analysis of which patterns of responsibility-embedding characterized distinct responsibility business model types.

Insert Figure 2 about here

Proposition. The first embedding pattern related to the value proposition centres on aspirational aspects. For instance, it includes sub-patterns referring to companies' social motivation and how they try to facilitate favourable stakeholder choices by addressing stakeholder demands. An example is Anglo American's proposition, promising 'stakeholders to find mutually beneficial solutions to our shared challenges.' Sub-patterns of the calibration pattern refer to the amount of distinct social, environmental and economic value created and how these types of value are calibrated, one against 
the other. For instance, Rio Tinto claims to "balance ... value for our shareholders and ... for the communities". The elements-of-proposition pattern covers sub-patterns defining a variety of value types and distinct beneficiaries as well as how value is embodied in company products and services, such as Centrica's proposition to 'offer innovative low carbon, energy efficient products and services.'

Creation. The first responsibility-embedding pattern in value creation —operationality — covers subpatterns explicitly related to operational aspects, such as social issues in operations or eco-efficiency. G4S, for example, focuses on 'health and safety, and ethical business practices across our operations.' The structures pattern includes policies of responsible governance and responsibility programmes, such as Diageo's 'global structure and shared services designed ... [for] governance of controls, compliance and ethics.' The patterns of human actors and their decisions and corresponding subpatterns relate to the human element of responsibility-embedded value creation. For example, Unilever stresses that their value creation relies on 'people motivated by doing good while doing well.' The pattern of integrating responsibility includes sub-patterns of integration into culture and across business functions, as Shire's statement exemplifies: 'responsibility at Shire has always been embedded ... never separated from our daily business activities, decisions and relationships.'

Exchange. Value exchange, the value function with the largest number of mentions, consists of three main patterns, each comprising many sub-patterns. First, the relationality pattern brings together various relational aspects of exchange, such as describing different types of relationships and their positive relational qualities such as GlaxoSmithKline's 'transparency, integrity and respect for people'. Secondly, the modes-of-exchange pattern includes relational arrangements like cocreation and partnerships, dialogue, and material exchange. For instance, Fresnillo's value exchange strongly relies on 'maintain[ing] mutually respectful relations with local labour unions through continuous dialogue and collaboration' Thirdly, the pattern describing companies' counterparts-in-exchange covers a list featuring all types of distinct stakeholders of the FTSE100. An example is Capita's emphasis on 'delivering value directly and indirectly to all our stakeholders: our clients, employees, shareholders, suppliers and the communities.' 
Capture. Finally, in value capture the main pattern of consequentiality covers the business models' multiple bottom lines and responsibility patterns related to how this value is captured. For instance, SSE claims that their 'actions are ethical, responsible and balanced, helping to achieve environmental, social and economic well-being for current and future generations.' The responsibility-measurementand-evaluation pattern gathers different sub-patterns related to making sure captured value is being accounted for, such as Tullow highlighting their 'EHS scorecard [measuring] social performance.' The categories growth and development, and outcomes are highly related. The latter creates an appreciation of outcome characteristics, such as being long-run-oriented, the ultimate impact, or scale. For instance, Kingfisher's aspired value capture is 'to have a positive impact on the world ... Net Positive ... We believe this gives us a 'licence to operate' for the long-term.' The former, growth and development, relates to how captured value should be used, including social investment, redistribution to stakeholders, or company reproduction. Old Mutual's value capture in communities is a good example: 'Returns to communities: Our support for communities is not just about giving money..., but about making real and sustainable positive impacts ... to build a stronger society ... especially in the emerging markets.'

\section{Responsibility Business Model Types}

Figure 3 illustrates the business model framework which explains the emergence of two types of homogeneous commercial business models (Types A and B) and four types of heterogeneous responsibility business models (Types 1-4). The figure highlights that distinct FTSE100 corporations operate in distinct spaces with different salient stakeholders, and therefore different constellations of institutional complexity and intensities of institutional demands. Each space uniquely enables and constrains strategic responses regarding the embedding of responsibility into business models.

Insert Figure 3 about here

Spaces of institutional complexity. First, there is a homogeneous space of low institutional complexity, visualized on the left side of Figure 3. Only B2B corporations inhabit this space of commercial-logic demands between commercial players (suppliers, competitors, commercial clients, 
economic regulators). Through their interaction, they continuously recreate an institutional logic of the commercial market. Companies in this space are barely known to the wider public, such as the information company Experian or business support services like Bunzl.

A second space located on the far right is inhabited by B2C corporations, including the clothing manufacturer Burberry and the retailer Marks \& Spencer. Their interaction with endconsumers places them firmly in the public eye, which creates at least moderate demands related to responsibility in addition to commercial-logic demands. As corporate responsibility becomes increasingly taken-for-granted, demands for responsibility rise. This is particularly relevant in the United Kingdom as a leading nation in responsibility implementation. Therefore, B2Cs from the onset operate in a heterogeneous space where they must both respond to commercial and responsibility demands.

In a third space in the middle, companies experience commercial and heightened institutional demands for responsibility. Companies may enter this space due to their industry's bad reputation, leading to societal scrutiny. Examples are the banking industry after the global financial crisis, or the mining industry, infamous for dangerous work and environmental destruction. Also, individual corporations may enter this space due to social, environmental, or ethical scandals. For instance, the pharmaceutical company GlaxoSmithKline was involved in healthcare fraud, bribing doctors in 2013. This space of heightened institutional demand is inhabited by both B2Cs and B2Bs from high-scrutiny industries or which were involved in scandals.

Strategic responses to commercial-responsibility logics. How can we explain that companies in the same space of institutional complexity display distinct types of business models? First, companies in the homogeneous commercial-logic space do not have to respond to responsibility logic demands. Accordingly, they have the freedom either to choose to carry on with a purely commercial business model or to morph responsibility elements into a commercial logic. We label the business models resulting from the choice to carry on Uncontested Commercials (Type A). These purely commercial business models are not challenged by demands for responsibility. Examples include the B2B food producer Associated British Foods and the construction materials wholesale corporation $\mathrm{CRH}$. We 
label the business models resulting from the choice to morph Discretionary (Type 1). Discretionaries make a discretionary choice to embed responsibility, although there are no institutional demands for doing so in their space. Examples include the security company G4S and the papermaker Mondi.

Secondly, companies in the space of the heterogeneous commercial logic on the right respond to moderate demands for the responsibility logic, which leaves them with a choice to either reactively conform with the demands or to proactively signal a heightened level of responsibility-embedding. Reactives (Type 5) make the choice to conform, examples of which are Intercontinental Hotels and telecom company Vodafone. Proactives (Type 6) make the choice to signal instead and include wellknown responsibility leaders such as Unilever and less well-known corporations with a strong intrinsic social responsibility component such as the specialized pharmaceuticals company Shire.

Thirdly, companies in the middle space face fierce demands to respond to a responsibility logic in addition to the commercial logic. They are left with two extreme choices. They can either hide from the demands by not embedding responsibility to avoid further criticism or to (over)compensate for past wrongdoings through intensive embedding. We label companies hiding from demands Contested Commercials (Type B), as their purely commercial-logic business model is under attack from responsibility-logic demands. Examples are the retailer Sports Direct, under scrutiny due to its labour conditions, and the energy companies Shell and BG, which are under attack for their contributions to climate change. The (over)compensating companies are labelled Reactives (Type 2) as their responsibility-embedding is best characterized as a reaction to the intensive demands. This group includes Tobacco, Alcohol or Petroleum companies responding to the heightened industry scrutiny and companies involved in scandals such as GlaxoSmithKline (see above).

As the framework shows, companies in the same industry can have great variety in their business model type. In food retailing, for example, M\&S is a Proactive, Sainsbury's and Morrisons are Reactives, and Tesco is a Remedial. Variation can be explained through the available strategic responses in companies' respective spaces of institutional complexity. Sainsbury's and Morrisons decided to conform to responsibility demands while Marks and Spencer instead chose to signal leadership in responsibility through their pioneering Plan A sustainability initiative, at the core of their 
business model. Both types of strategic response correspond to the space of moderate heterogeneous demands that all three inhabit. Tesco, however, is a Remedial because it had to make up for the horsemeat scandal that had pushed it into the heightened scrutiny space. Given the food industry's advanced responsibility practices, it could not afford making a choice to hide and lose ground in comparison to its competitors.

\section{Unique Patterns of Responsibility Business Model Types}

In the first step we identified the responsibility patterns of all FTSE100 business-model artefacts, while the second step led to the proposition of four types of responsibility-embedded business models. We can corroborate these four types if we would find a distinct pattern for each type and even more so if the pattern matched the distinctive strategic responses suggested by our framework. For instance, we would expect Remedials to favour patterns of responsibility-embedding corresponding to their need to show that they are making up for past wrongdoings. This could result in a pattern of wide and varied embedding to cover all bases of what a critical stakeholder would expect from them. We will analyse such patterns for all four business model types and critically examine their correspondence to our framework's explanations for each type.

This last part of the findings focuses on analysing the responsibility-embedded business model Types 1-4 (Discretionaries, Remedials, Reactives, Proactives) only. We omit the two homogeneously commercial Types A and B, because they did not display any responsibilityembedding. We now explain each type's responsibility-embedding pattern based on the comparative frequency Table A. 2 (Appendix). The table shows the company-average number of codes per pattern of responsibility-embedding which reflects the intensity of embedding into business model artefacts. By comparing distinct intensities of particular patterns between the four responsibility business model types, we are able to grasp the unique patterns of embedding that allow distinguishing the types. ${ }^{4}$ For instance, Proactives, with an average of 7 responsibility-embedding mentions per company in value proposition, have a comparative focus on this function unlike other types with averages of 5.4

\footnotetext{
${ }^{4}$ Frequency counts in appendix Table A. 2 express the intensity of responsibility-embedding patterns, with numbers in parentheses referring to the numbered lines in the table. The darker the shade of the cells in the table, the higher the intensity of a particular pattern in one type in comparison to the other types of responsibility business model artefacts.
} 
(Remedials), 4.8 (Reactives), and 3.4 (Discretionaries) (3). ${ }^{5}$ Table A. 2 also offers fine-grained insights into business model types. For instance, Discretionaries lead among all companies in claiming to integrate responsibility in their operations (25-27), and Proactives lead in dedicated responsibility programmes becoming part of their business models (36).

There are two overall leaders in the intensity of responsibility-embedding into artefacts, Proactives with an average of 36 codes per business model and Remedials with 29 (2). This observation matches the strategic response suggested to be underlying these business model types: Proactives excel in embedding responsibility because they tend to signal leadership, while Remedials have a high intensity of embedding to (over)compensate for industry or company scandals. Two types displayed a considerably lower embedding intensity into artefacts: Reactives with an average of 22 mentions and Discretionaries with 18. Reactives' strategic response is doing the minimum of responsibility-embedding necessary to conform to demands. Discretionaries' response is to cherrypick a few responsibility elements that can be morphed into a commercial logic.

We will now explore how each responsibility business model type manifests in such distinct patterns of embedding. Table 1 provides a comparative overview of Discretionaries', Remedials', Reactives' and Proactives' patterns of responsibility-embedding.

Insert Table 1 about here

Discretionaries. Discretionaries are located in an institutional space of homogeneous commercial demands. Accordingly, they respond by morphing particular responsibility elements so that they make commercial sense. This pattern is in line with the observation that the main stakeholders mentioned are core commercial stakeholders, namely suppliers and partners (60), employees (56), economic regulators (57) and shareholders (58). Due to the absence of responsibility demands in their institutional space, embedding responsibility elements that are not aligned with commercial considerations would not be legitimate in the eyes of these commercial stakeholders.

\footnotetext{
${ }^{5}$ Numbers in parentheses refer to the respective lines of Appendix Table A.2 for further reference.
} 
Accordingly, Discretionaries have the lowest intensity of all types in communicating an intrinsic social motivation (4) in the business model artefacts. The purely commercial logic of Discretionaries' institutional space is strongly reflected in their patterns of embedding. In all functions but value creation, Discretionaries show the lowest level of embedding responsibility elements (1). We will not explain Discretionaries value proposition or exchange as no distinctive patterns were identified.

In the value creation function (14), Discretionaries come in second-last, surpassing Reactives, but behind Remedials and Proactives. However, Discretionaries lead among all business model types in the value creation element of integrating responsibility (23) into a largely commercial culture and across commercial operations $(24,25)$. Embedding responsibility into operational value creation activities is comparatively easy to justify commercially. Therefore, they lead in ecoefficiency (17) and social issues in operations (18). Eco-efficiency saves costs by saving environmental resources used as production inputs, making these both 'environmental and cost efficiency factors' (Land Securities). Social issues in operations like 'health and safety (...) and ethical business practices' (G4S) may easily be linked to a risk of commercial losses.

The need to cloak responsibility elements under a commercial logic is also visible in value capture. Discretionaries emphasize the importance of linking responsibility-embedding to performance and economic success (71). They lead among all business model types in interpretation and standardization (70), with all their responsibility standards being related to employee wellbeing, which, in turn, can be linked to commercial productivity (60). A statement in British Land's business model artefact exemplifies this: 'We again achieved (...) accreditation in the Sunday Times Best companies to Work for survey. We ranked in the top five FTSE 100 companies for reporting wellness and engagement of employees in the (...) Workwell Benchmark'. Overall, Discretionaries' patterns of responsibility-embedding all relied on morphing responsibility into commercially legitimate elements of a business model, responding to a purely commercial institutional space.

Remedials. Remedials are located in a heterogeneous institutional space characterized by ambiguity between commercial and responsibility demands. Due to past saliency of responsibility issues, this space has heightened demands for a responsibility logic. Remedials' strategic response is to 
(over)compensate for past transgressions by intensively embedding responsibility into their business model (average embedding mentions 29.4). They are close behind Proactives and far ahead of Reactives and Discretionaries. Remedials rank closely behind Proactives in responsibility-embedding in value proposition (2), creation (14), and capture (62), and even surpass them in value exchange (35).

Facing intense scrutiny, Remedials cannot afford to be found committing yet another transgression against the responsibility logic. Accordingly, they try to cover all bases which is most apparent in their value proposition. They claim to be balancing value (9) for a wide variety of beneficiaries (11) and interact with many different stakeholders (52-61). An example is Anglo American's statement claiming to create 'an attractive and differentiated value proposition for our partners and stakeholders.'

In value creation, Remedials excel in operational aspects (15-18) to avoid further criticism. Examples are Tesco's 'operating responsibly' or [the bank] Lloyds' 'operating sustainably'. Remedials stress the role of employees (56) as main human actors (26-29) to do the right thing because a single wrongdoing could have grave consequences, given the level of scrutiny. Accordingly, governance of responsibility (31), responsible decision-making (21) and behaviour (22) are also stressed.

In value exchange, Remedials outperform even Proactives' embedding intensity in business model artefacts (35). Remedials' strategic response to (over)compensate implies a need to show that they have changed towards responsibility and away from past transgressions. Value exchange, with its nexus of relationships, is the perfect stage for this message to be conveyed. Remedials lead by far in describing their good relational qualities (38) and practices such as 'respectful relationships' (Fresnillo), 'transparency and integrity' (Glaxo Smith Kline), and 'trusted relationships' (Old Mutual). They stress to be doing the right thing for a wide variety of stakeholders (53). However, they focus particularly on regulators (57) to whom they try to prove themselves, due to past wrongdoings of breaking the law. Remedials stress engagement in a wide variety of modes of exchange (42) but do not seek a close engagement with single groups as this could direct attention away from other stakeholders (47). 
In a similar vein, Remedials claim to contribute to multiple bottom lines (64). In value capture, they aim to cover all aspects of responsibility-embedding but standardization (70). Delving too deeply into efforts to comply with individual standards would take away resources to cover all the other embedding aspects in parallel.

Reactives. Reactives also operate in a heterogeneous institutional space but the responsibility demands are not as intense as for Remedials. Reactives are not subject to heightened scrutiny. They are free to choose to conform to moderate responsibility demands, sufficiently so to achieve legitimacy but not beyond. The textbook publisher Pearson exemplifies this search for legitimacy by the external evaluation of social impact: 'We will ... invite others to judge us - not by the products that we make but by their impact on learners.' Such orientation by external legitimacy judgment is palpable in Reactives' patterns of responsibility-embedding. In line with the strategy to conform to societal demands, (after shareholders) Reactives' most frequently mentioned community (54), customers (55), and wider society (59). Given their institutional space's responsibility demands, they show a slightly higher intensity of responsibility-embedding than Discretionaries but are far removed from the embedding intensity of Remedials and Proactives (1).

Reactives have the second lowest embedding intensity in business model artefacts' value proposition (2). They cover most of the elements of a responsibility value proposition, but with low intensity, leading in none (5-13).

Reactives score lowest when it comes to embedding responsibility into the value creation function (14). Reactives' strategic response, aiming for minimum effort, would be inconsistent with the complex and committed work of deeply embedding responsibility into value creation activities. Consistent with this argument, Reactives also score lowest in creating lasting responsibility structures (30) and none mention a company-wide responsibility programme (34).

In value exchange, though, Reactives do search for close engagement with selected stakeholders (47) and for the provision of benefits (45). These practices centre on an active 'community engagement process' (Taylor Wimpey) leading to initiatives like National Grid's volunteering 'for community-based projects.' Consistent with the choice to conform to responsibility 
demands without affecting commercial operations, such initiatives are isolated from core operations. This also corresponds to Reactives' artefacts lowest intensity in involving suppliers and partners (60) and other commercial stakeholders like employees (56) and economic regulators (57). Along the same lines, they rank last in mentioning valuable instrumental relationships (48) related to responsibility.

Reactives' pattern to create minimum interference with commercial activities also shows in value capture: economic factors related to responsibility play the weakest role among all business model types (72). Overall, Reactives also have the second lowest embedding intensity in business model artefacts' value capture (62). Mirroring the pattern in their value proposition, Reactives' business model artefacts' value capture covers a wide variety of aspects but typically with little intensity (67-72). 'Stronger' forms of responsibility-embedding that would require longer and deeper commitment are avoided. For instance, they show the lowest attention to concerns for ensuring impact (79) and for the longevity of responsibility measures (81).

Proactives. Proactives share the institutional space (moderately intense heterogeneous logic) with Reactives, but instead make a choice to actively signal their leadership by intensively embedding responsibility. As a result, Proactives' average embedding of 36 responsibility elements per business model is considerably higher than the 22 of Reactives (1). Both types differ even more significantly in the qualitative nature of their embedding activities.

Proactives clearly lead in embedding responsibility into their value proposition (2), as a dedicated decision to signal their leadership. They make their social motivation (4) explicit three times as often as the next frequent type. Proactives communicate their intrinsic motivation by deemphasizing their dependence on external stakeholders as a reason (5) for doing responsibility. Their motivation often relates to proactively tackling larger societal and environmental issues $(59,61)$, such as the pharmaceutical company Shire which aligns their business model to transform the lives of people around the world whose health is impacted by rare and other specialized conditions.'

Proactives lead in responsibility-embedding into products and services (13) and are most sophisticated in calibrating amount and type of value (7-9) proposed. 
In value creation, Proactives lead by differentiating their unique advanced responsibility activities, showcasing ambitious, company-wide responsibility programmes (35). For instance, Unilever highlights the connection between their responsibility programme and business model: 'The differentiator in our business model is our Unilever Sustainable Living Plan. ' More generic operational aspects are de-emphasized in the business model (15-18) and subsumed under a larger 'good business' approach (20). This approach integrates responsibility (23) deeply into culture (24) and across business functions (25), by creating structures (30) and providing resources (33).

The only business model function in which Proactives do not lead is embedding responsibility into value exchange (35). Unlike Remedials and Reactives, Proactives do not try covering all possible value exchange activities. Instead, they differentiate themselves by assuming leadership in and focussing on fewer but deeply embedded activities. Proactives' approach to value exchange is in line with their focus on embedding responsibility into the value proposition and into commercial operations. They highlight the importance of key instrumental relationships $(37,48)$ with customers (55), suppliers, and partners (60) to co-create responsibility activities (49). To also ensure good responsibility practice in relationships with non-core partners, Proactives most strongly rely on relational hubs (39) that represent a bundled interface to connect with a wide variety of stakeholders. For instance, the shopping centre company Intu stresses, 'reinforcing our centres' role as vital hubs for the community' as a key relational aspect. Proactives' strong public identification with their responsibility initiatives creates an intimate relationship between responsibility and brand (41).

Proactives are uncontested leaders in embedding responsibility into value capture, with Remedials as the second-best type displaying only half the intensity (62). Proactives lead in all but two value-capture patterns (63-81). They show what differentiates their responsibility value capture by individuating specific impacts (79) and showcasing a variety of forms of capture (65). However, they rarely make use of the term triple-bottom line (64), possibly as it would be too generic to serve as differentiator in signalling leadership. Proactives translate social ambitions into customized responsibility measurement and evaluation (67-72), entangled with economic aspects. Whitbread, the corporation behind Costa Coffee exemplifies this through the evaluation of their responsibility programme 'Good together', entangled with more commercial aspects: 'We set key performance 
indicators for Winning Teams, Customer Heartbeat, Profitable Growth and Good Together ... clear and measurable targets which together make up our balanced scorecard or WINcard (Whitbread In Numbers). ' However, Proactives barely mention generic external standards (70) that would distract from their highly customized responsibility-embedding.

Proactives' responsibility value capture is intimately entangled with economic factors (72), including company identity, reputation and brand (41). Proactives also show great concern for outcomes (78) of responsibility as these influence their economic fate. Proactives pay particular attention to responsibility impact (79), the scale of responsibility initiatives (80), and their development over time (81). For instance, M\&S claims to 'work hard to engage our customers in Plan A - the more we involve them, the greater impact we will have'. Kingfisher stresses their longterm ambitions of 'creating employment and a brighter future for our people, the environment and wider communities, creating a "licence to operate" long-term.'

\section{DISCUSSIONS, CONTRIBUTIONS, FUTURE RESEARCH}

This paper contributes to the interrelated discussions of heterogeneous business models, strategic organization of corporate responsibility, and strategic responses to institutional complexity arising from distinct compositions of salient stakeholders.

\section{Expanding Heterogeneous Business Models Studies}

This paper is the first to apply the lens of heterogeneous business models in an empirical study. The conceptualization of heterogeneous business models had been derived from the literature (Laasch, 2018b; Ocasio \& Radoynovska, 2016) but lacked empirical corroboration. We also contribute to the discussion of alternative business models shaped by institutional logics beyond the commercial one (Arend, 2013; Randles \& Laasch, 2016). Our findings that show distinct patterns of responsibilityembedding into the FTSE100 corporations' commercial value logic provide empirical evidence for both conceptual discussions.

This paper's empirical operationalization of the meta-logic of value proposition, creation, exchange and capture, proposed by Laasch (2018b), pioneers a methodological device for future studies of all kinds of heterogeneous business models. Examples are family businesses (commercial- 
family logics), state-owned enterprises (commercial-governmental logics), and social enterprises (commercial-social welfare logics). Allocating and studying the unique embedding patterns of responsibility and commercial logics across business model functions of value proposition, creation, exchange and capture, provides opportunities for a more detailed study of the interplay of responsibility and commercial factors. It provides more nuanced insight than the discussion of how corporate responsibility and sustainability may serve as unique strategic resources leading to competitive advantage (Russo \& Fouts, 1997; Sharma \& Vredenburg, 1998), which typically makes high-level, whole-organization statements. In comparison to typologies that have emerged from this resource-based and business-case perspective (e.g. Orsato, 2006), the heterogeneous value logics lens provides an interconnected appreciation of the different responsibility patterns of embedding in and across value proposition, creation, exchange and capture.

By using this meta-value logic lens, our paper also provides a refined insight into varieties of embedding patterns behind recent higher-level classifications such as placing responsibility inside or outside the core business model (Stål \& Corvellec, 2018). We show that companies in a purely commercial space are likely to have responsibility-embedding in value creation that blends into commercial operations, such as eco-efficiency and safety initiatives, as well as value capture responsibility-embedding, highlighting how responsibility elements improve commercial performance. Conversely, the interconnectedness between value functions, forming a coherent value logic, allows for reassembling 'atomic', somewhat isolated responsibility-embedding patterns found in business models (e.g. Lüdeke-Freund et al., 2018; Muñoz \& Cohen, 2018) back into a coherent higher-order logic of responsibility-embedding types based on their typical combination of these patterns. As an example, the business model patterns in the purely commercial space with their particular value creation and capture can be described as the coherent higher-level value logic of a 'Discretionary' type.

Our study's two main limitations direct our attention to meaningful gaps in what we know about heterogeneous business models, which future research might address. Firstly, the information provided in annual reports works well for studying the successful integration of the heterogeneous logics but is unlikely to communicate misalignments, tensions, or paradoxes between the logics as 
companies tend to present their successes, not their struggles. Further research might harness other data sources, such as interviews and ethnographies, to study the complex nature (Smith et al., 2010) and tensions (Hahn et al., 2015; Van der Byl \& Slawinski, 2015) of heterogeneous business models. Secondly, there is a risk that the requirement to include a business model artefact into the annual report leads companies to pay lip service, while not walking the talk. The strict reporting requirements (FRC, 2012), the increasing maturity of responsibility reporting practices in integrated reports (Jensen \& Berg, 2012), and reputational dangers of greenwashing (Delmas \& Burbano, 2011; Laufer, 2003) reduce this risk. Particularly Reactives, with their often vague statements of responsibility-embedding, are the most likely to engage into decoupling (Crilly et al., 2012; Fiss \& Zajac., 2006; Jamali et al., 2015; Stål \& Corvellec, 2018). Further research, through a decoupling lens but also from a communicative constitution of responsibility perspective (Caruana \& Crane, 2008; Christensen et al., 2013; Schöneborn \& Trittin, 2013), could shed light on the relationship between responsibility business models as they are communicated and enacted.

\section{Distinctions and Dynamics of Spaces of Institutional Complexity}

Our framework suggests that the stakeholder-related characteristics of institutional complexity in a particular space constrain and enable strategic responses. The constraining effect comes from the heightened responsibility demands, where conforming only is not an option. In this space, heightened scrutiny by responsibility-logic stakeholders, particularly private customers and wider society leads to high demands for responsibility-logic responses. Therefore, corporations' strategic responses are limited to the two extremes of hiding or (over)compensating. As we see in Proactives, though, the characteristics of a heterogeneous institutional space may also enable new strategic responses. The co-existence of commercial and responsibility logics in the space of moderate heterogeneous demands creates ambiguity. Proactives use this ambiguity to legitimize their proactive responsibility-embedding, which would be impossible in a homogeneous commercial space inhabited by salient commercial-logic stakeholders like suppliers, economic regulators, and B2B customers.

The spaces of institutional complexity we found are distinct from extant conceptualizations of space(s) in organizational institutionalism. Firstly, our conceptualization of institutional spaces relates 
to demands of institutional spaces defined by national boundaries (Ethington \& McDaniel, 2007; Gaur et al., 2007; Kostova \& Zaheer, 1999; Manolova et al., 2008) that influence organizational configurations (Martin et al., 1994; Oteman et al., 2014). Yet, in our understanding of institutional spaces there is less influence arising from national legal and regulatory aspects of institutionalization reflecting demands by national governments. Instead, a more prominent role is given to the demands from other stakeholders dominating each space. For instance, in the homogeneous commercial-logic space, the main legitimacy-providing stakeholders are B2B customers, business partners, and suppliers. In the heterogeneous commercial space, the moderate responsibility-logic demands come from private customers and the general public. Secondly, we share the idea of membership with the institutional fields discussion (Cooney, 2006; Lawrence \& Phillips, 2004; Purdy \& Gray, 2009; Suddaby \& Viale, 2011; Zietsma \& Lawrence, 2010). However, organizational membership in spaces of institutional complexity not only depends on affiliation with a certain industry or organizational characteristics, but also on an organization's individual behavior. Particularly corporate scandals or remedial efforts can move corporations from one space to another. Thirdly, spaces of institutional complexity share the availability of alternative institutional logics for strategic respones with the discussion of interstitional, white, and hybrid spaces (Furnari, 2014; Martin, 2008; Perkmann, 2018; Raynard, 2016; Suddaby \& Viale, 2011). Distinct from the existing literature focussing on intraorganizational or inter-organizational spaces, we conceptualize organizations' entire institutional environments as demarcated heterogeneous spaces. Finally, spaces of institutional complexity are a type of complex institutional environments (Greenwood et al., 2011; Mohr \& Guerra-Pearson, 2010; Schildt \& Perkmann, 2016; Scott \& Meyer, 1994). We add to this discussion the important aspect of their demarcated nature: The location of a company inside or outside a space's boundaries distinguishes the type of institutional complexity it responds to, leading to distinct responses from seemingly similar companies in an industry. In summary, our paper's finding of co-existing spaces of institutional complexity suggests a novel concept for the analysis of strategic responses to institutional complexity.

Future research may study institutional change of and in such spaces of institutional complexity. How do activities (Katzenstein, 1998) and identities (Alsup, 2006; Gibson \& Macleod, 
2012; Glynn, 2008; Korovkin, 2003; Scott \& Lane, 2000) of incumbents of such spaces change longitudinally (Wallis \& Ison, 2011). Neither do we know what happens after organizations cross the boundaries between spaces. In the FTSE100 context, one could study how organizations change when moving from one space into another after a scandal. Future studies could also focus on the dynamics of stability and change of the space itself, that is, new institutionalization, co-construction, and reconstruction of spaces over time (Carson, 2008; Codó \& Pérez-Milans, 2014; Cooren et al., 2005; Duncan, 2013; Jones et al., 2004; Mohanty, 2004). In consequence, how do spaces expand or contract and how do their boundaries change in the process (Sage et al., 2016; Zietsma \& Lawrence, 2010)?

\section{Studying Responsibility Business Models in Context}

From an institutional perspective on corporate responsibility, the comparison between spaces provides a nuanced appreciation of companies' responsibility-embedding that might go unnoticed otherwise. For instance, the intensity of embedding responsibility elements into business model artefacts between Remedials and Proactives is very similar, but, being in distinct spaces, the patterns of their embedding are entirely different. Without the appreciation of distinct institutional spaces, we would not have identified Discretionaries as responsibility leaders given their comparatively low intensity of embedding. Still, in their specific space they are leaders as they take a discretionary decision for responsibility that goes against the commercial logic of their space. Another example for the more nuanced understanding of responsibility-embedding, or rather non-embedding, is the distinction between Uncontested and Contested Commercials. They appear indistinguishable, as neither embeds responsibility. However, given their location in distinct institutional spaces, we learn that their lack of embedding stems from different strategic responses. Uncontested Commercials do not embed responsibility because there are no demands to do so in their homogeneous commercial space. Contested Commercials, on the other hand, refrain from embedding as they are unlikely to satisfactorily respond to the high responsibility demands in their space. This insight is of particular relevance for political efforts to promote responsibility-embedding. Uncontested Commercials could be motivated to embed responsibility by breaking up the homogeneous commercial institutional space and inserting responsibility demands through legislation. For Contested Commercials, however, 
increasing the responsibility demands might rather lead to further entrenchment of their purely commercial business models.

Our framework enables more nuanced analyses of business-society interactions in between and across distinct spaces of institutional complexity. This appears particularly promising in relation to the distinct modes and intensities of responsibility (Berry \& Rondinelli, 1998; Clarkson, 1995; Groza et al., 2011; Torugsa et al., 2012). Leadership in responsibility-embedding may look very different across distinct spaces of institutional complexity. Proactives, for instance, led embedding efforts in the moderately heterogeneous space, Remedials did so in the space of heightened responsibility demands, and Discretionaries in the homogeneous commercial-logic space. Future comparative research may study organizational leadership and followership in responsibility across distinct spaces.

\section{Zebras' Stripes vs Leopards' Spots: The Heterogeneous Organizing of Corporate Responsibility}

In this paper, we provide a counter-piece to an article titled 'How the zebra got its stripes' (Lee \& Battilana, 2013). The play on words between these two papers alludes to their commonality, the study of heterogenization. As Zebra and Leopard, social enterprises and commercial corporations are quite different animals. Unlike social enterprises, corporations enter the 'hybrid spectrum' from the commercial end (Alter, 2007, p. 14). Social enterprises rely on heterogenization processes where a commercial logic becomes integrated into a social welfare logic (Spieth et al., 2018). Conversely, forprofits heterogenize commercially-dominated structures through responsibility-embedding.

Our framework primes a novel discussion of heterogeneous organizing in the corporate context. It provides a map of the institutional spaces and responsibility business models inhabiting them. This map contrasts with a parallel discussion in the social enterprise context, providing typologies of heterogeneous social enterprise ventures (Lee \& Jay, 2015; Santos et al., 2015). This discussion also connects heterogeneous organizing to responses to demands from institutional logics in the topical context of corporate responsibility (Aharonson \& Bort, 2015; Meyer \& Höllerer, 2016; Raynard, Lounsbury, \& Greenwood, 2013; Testa, Boiral, \& Iraldo, 2015; Westermann-Behaylo, M., Berman, \& Van Buren, 2013). The discussion of heterogeneous organizing for responsibility could 
benefit from cross-fertilization with the social enterprise context. Heterogeneous social enterprises often experience a drift from a social to a commercial mission (Ebrahim et al., 2014). Future research could explore responsibility corporations' reverse mission drift from commercial to social by studying changes in their value proposition. An example is the commercial-logic attacks from activist shareholders on Unilever's responsibility-embedded business model due to perceived mission drift. ${ }^{6}$

Another contribution relates to the type of response found, namely the embedding of responsibility-logic elements into a dominant commercial logic: The leopard's spots. This finding is complementary with Rauter et al.'s (2017) insight that sustainable business models are often constructed through adaptations and extensions of traditional commercial business models. This combination, with one logic remaining dominant, is particularly relevant in spaces where the intensity of logics' demands is unequally distributed. Further research could explore the organizing processes through which alternative-logic spots emerge in commercial strategic artefacts and thus connect to Gond et al.'s (2017) study of the opposite process of how responsibility artefacts become commercially strategic.

\section{Managerial Implications}

Our findings have direct implications for management practitioners (e.g. business model strategists, corporate responsibility professionals, and report writers) engaged in the embedding of responsibility in business models. Firstly, the framework of responsibility business model types and the responsibility-embedding patterns can be used as orientation for corporate practitioners while embedding responsibility elements into their business models. Practitioners at the FTSE100 corporations, due to novel requirements, are pioneers in embedding responsibility into their business models. Our paper makes their efforts accessible to and imitable by other practitioners in the process of embedding responsibility in their own business models. Secondly, our framework of strategic responses in distinct institutional spaces illustrates embedding or non-embedding options to business model practitioners, depending on the strategic environment of their organization. For instance,

\footnotetext{
${ }^{6} \mathrm{https} / / / \mathrm{www}$. forbes.com/sites/econostats/2017/03/15/unilever-and-the-failure-of-corporate-socialresponsibility/\#7aa38e3f498d
} 
corporate responsibility managers in a $\mathrm{B} 2 \mathrm{~B}$ company operating in an entirely commercial institutional space may find two valuable insights from our framework. On the one hand, they will see that it is possible to simply not embed responsibility into their business model (Uncontested commercial business model) as the company's space does not demand it. On the other hand, they could also choose to embed responsibility by morphing it into a commercial guise, constructing a business model type similar to Discretionaries in the FTSE100. Accordingly, our framework makes practitioners aware of the choices they have. What kind of responsibility-embedding is likely to work, or not, depending on the strategic institutional space they operate in.

\section{CONCLUSION: EXPLAINING THE LEOPARDS' THEIR SPOTS}

This paper has explored the phenomenon of responsibility-embedding in commercial business model artefacts. We have developed an explanatory framework from the analysis of the FTSE100 business model artefacts, which enables us to respond to our questions of 'What kind of spots the leopards got and why'? We explain varieties of responsibility business models, 'spotted' with responsibility logic patterns through corporations' strategic responses in distinct spaces of institutional complexity. These spaces both enabled and constrained available responses. We identify four types of such responsibility business models: (1) As Discretionaries are located in an institutional space of homogeneous commercial demands, they morph responsibility elements to make commercial sense;

(2) Remedials' heterogeneous institutional space is characterized by an ambiguity between commercial and responsibility demands, due to past responsibility transgressions which leads them to (over)compensate by intensively embedding responsibility; (3) Reactives operate in a heterogeneous institutional space with less intense demands, allowing them to conform to achieve legitimacy with moderate intensity of responsibility embedding; (4) Proactives share the same institutional space but choose to actively signal their leadership by intensively embedding responsibility to emerge as progressive responsibility leaders. Despite showing distinct patterns of responsibility embedding, all four types of responsibility business models fit the following definition: 
Responsibility business models are commercially dominated heterogeneous value logics that embed responsibility elements across their value proposition, creation, exchange, and capture.

First, we contribute to the heterogeneous business model literature by providing an empirical proof of concept. Secondly, we explain why distinct types and patterns of responsibility business models exist, contributing to an institutional perspective on corporate responsibility. Third, we extend hybrid, or rather heterogeneous organizing theory from the social enterprise context to corporate responsibility. Finally, our framework is useful for practitioners to explore what types of responsibility business models are feasible in their respective institutional spaces, and as a source of inspiration from the varieties of patterns of responsibility-embedding that we found. 


\section{REFERENCES}

Abdelkafi, N., \& Täuscher, K. (2016). Business models for sustainability from a system dynamics perspective. Organization \& Environment, 29(1), 74-96.

Aguilera, R. V., Rupp, D. E., Williams, C. E., \& Ganapathi, J. (2007). Putting the S back into corporate social responsibility: A multilevel theory of social change in organizations. Academy of Management Review, 32(3), 836-863.

Aharonson, B. S., \& Bort, S. (2015). Institutional pressure and an organization's strategic response in Corporate Social Action engagement: The role of ownership and media attention. Strategic Organization, 13(4), 307-339.

Alsup, J. (2006). Teacher identity discourses: Negotiating personal and professional spaces. Milton Park: Routledge.

Alter, K. (2007). Social enterprise typology. San Francisco: Virtue Ventures LLC.

Arend, R. J. (2013). The business model: Present and future - beyond a skeumorph. Strategic Organization, 11(4), 390-402.

Aronson, J. (1995). A pragmatic view of thematic analysis. The Qualitative Report, 2(1), 1-3.

Aversa, P., Furnari, S., \& Haefliger, S. (2015). Business model configurations and performance: A qualitative comparative analysis in Formula One racing 2005-2013. Industrial and Corporate Change, 24(3), 655-676.

Banerjee, S. B. (2011). Embedding sustainability across the organization: A critical perspective. Academy of Management Learning and Education, 10(4), 719-731.

Battilana, J., \& Lee, M. (2014). Advancing research on hybrid organizing: Insights from the studies of social enterprises. The Academy of Management Annals, 8(1), 397-441.

Berry, M. A., \& Rondinelli, D. A. (1998). Proactive corporate environmental management: A new industrial revolution. The Academy of Management Executive, 12(2), 38-50.

Bertels, S., \& Lawrence, T. B. (2016). Organizational responses to institutional complexity stemming from emerging logics: The role of individuals. Strategic Organization, 14(4), 336-372.

Blenkhorn, D. L., \& MacKenzie, H. (2017). Categorizing corporate social responsibility (CSR) initiatives in B2B markets: The why, when, and how. Journal of Business \& Industrial Marketing, 32(8), 1172-1181.

Bocken, N. M., de Pauw, I., Bakker, C., \& van der Grinten, B. (2016). Product design and business model strategies for a circular economy. Journal of Industrial and Production Engineering, 33(5), 308-320.

Bocken, N. M. P., Short, S. W., Rana, P., \& Evans, S. (2014). A literature and practice review to develop sustainable business model archetypes. Journal of Cleaner Production, 65, 42-56.

Bohnsack, R., \& Pinkse, J. (2017). Value propositions for disruptive technologies: Reconfiguration tactics in the case of electric vehicles. California Management Review, 59(4), 79-96.

Bohnsack, R., Pinkse, J., \& Kolk, A. (2014). Business models for sustainable technologies: Exploring business model evolution in the case of electric vehicles. Research Policy, 43(2), 284-300.

Boons, F., \& Lüdeke-Freund, F. (2013). Business models for sustainable innovation: State-of-the-art and steps toward a research agenda. Journal of Cleaner Production, 45, 9-19.

Bowman, C., \& Ambrosini, V. (2000). Value creation versus value capture: Towards a coherent definition of value in strategy. British Journal of Management, 11(1), 1-15.

Boyatzis, R. E. (1998). Transforming qualitative information: Thematic analysis and code development. Thousand Oaks: Sage.

Braun, V., \& Clarke, V. (2006). Using thematic analysis in psychology. Qualitative Research in Psychology, 3(1), 77-101.

Breuer, H., \& Lüdeke-Freund, F. (2015). Values-based innovation framework: Innovating by what we care about The Proceedings of the XXVI ISPIM Conference. Budapest: International Society for Professional Innovation Management.

Breuer, H., \& Lüdeke-Freund, F. (2017). Values-based network and business model innovation. International Journal of Innovation Management, 21(3), 1-35. 
Carson, J. (2008). On discourse as monument: Institutional spaces and feminist problematics. In G. Pollock \& J. Zemans (Eds.), Museums after Modernism: Strategies of Engagement (pp. 190224). Chichester: Wiley.

Caruana, R., \& Crane, A. (2008). Constructing consumer responsibility: Exploring the role of corporate communications. Organization Studies, 29(12), 1495-1519.

Casadesus-Masanell, R., \& Ricart, J. E. (2010). From strategy to business models and onto tactics. Long Range Planning, 43(2), 195-215.

Chapple, W., \& Moon, J. (2005). Corporate social responsibility (CSR) in Asia: A seven-country study of CSR web site reporting. Business \& Society, 44(4), 415-441.

Chesbrough, H., \& Rosenbloom, R. S. (2002). The role of the business model in capturing value from innovation: Evidence from Xerox Corporation's technology spin-off companies. Industrial and Corporate Change, 11(3), 529-555.

Christensen, L. T., Morsing, M., \& Thyssen, O. (2013). CSR as aspirational talk. Organization, 20(3), 372-393.

Clarkson, M. B. E. (1995). A stakeholder framework for analyzing and evaluating corporate social performance. Academy of Management Review, 20(1), 82-117.

Codó, E., \& Pérez-Milans, M. (2014). Multilingual discursive practices and processes of social change in globalising institutional spaces: A critical ethnographic perspective. International Journal of Multilingualism, 11(4), 381-388.

Comi, A., \& Whyte, J. (2018). Future making and visual artefacts: An ethnographic study of a design project. Organization Studies, DOI: 10.1177/0170840617717094.

Cooney, K. (2006). The institutional and technical structuring of nonprofit ventures: Case study of a US hybrid organization caught between two fields. Voluntas: International Journal of Voluntary and Nonprofit Organizations, 17(2), 137-155.

Cooren, F., Fox, S., Robichaud, D., \& Talih, N. (2005). Arguments for a plurified view of the social world: Spacing and timing as hybrid achievements. Time \& Society, 14(2-3), 265-282.

Cornelissen, J. P., Durand, R., Fiss, P. C., Lammers, J. C., \& Vaara, E. (2015). Putting communication front and center in institutional theory and analysis. Academy of Management Review, 40(1).

Crilly, D., Zollo, M., \& Hansen, M. T. (2012). Faking it or muddling through? Understanding decoupling in response to stakeholder pressures. Academy of Management Journal, 55(6), 1429-1448.

Darby, L., \& Jenkins, H. (2006). Applying sustainability indicators to the social enterprise business model: The development and application of an indicator set for Newport Wastesavers, Wales. International Journal of Social Economics, 33(5/6), 411-431.

Deephouse, D. L., \& Suchman, M. (2008). Legitimacy in organizational institutionalism The Sage handbook of organizational institutionalism (pp. 49-77). Thousand Oaks: Sage.

Delmas, M. A., \& Burbano, V. C. (2011). The drivers of greenwashing. California Management Review, 54(1), 64-87.

Demil, B., \& Lecocq, X. (2015). Crafting an innovative business model in an established company: The role of artifacts. Advances in Strategic Management, 33, 31-58.

Demil, B., Lecocq, X., \& Warnier, V. (2018). "Business model thinking", business ecosystems and platforms: The new perspective on the environment of the organization.M@n@gement, 21(4), 1213-1228.

Doganova, L., \& Eyquem-Renault, M. (2009). What do business models do? Innovation devices in technology entrepreneurship. Research Policy, 38(10), 1559-1570.

Duncan, R. (2013). Opening new institutional spaces for grappling with uncertainty: A constructivist perspective. Environmental impact assessment review, 38, 151-154.

Dunn, M. B., \& Jones, C. (2010). Institutional logics and institutional pluralism: The contestation of care and science logics in medical education, 1967-2005. Administrative Science Quarterly, 55(1), 114-149.

Ebrahim, A., Battilana, J., \& Mair, J. (2014). The governance of social enterprises: Mission drift and accountability challenges in hybrid organizations. Research in Organizational Behavior, 34, 81-100. 
Emerson, J. (2003). The blended value proposition: Integrating social and financial returns. California Management Review, 45(4), 35-51.

Ethington, P. J., \& McDaniel, J. A. (2007). Political places and institutional spaces: The intersection of political science and political geography. Annual Review of Political Science, 10, 127-142.

Fereday, J., \& Muir-Cochrane, E. (2006). Demonstrating rigor using thematic analysis: A hybrid approach of inductive and deductive coding and theme development. International Journal of Qualitative Methods, 5(1), 80-92.

Fiss, P. C., \& Zajac., E. J. (2006). The symbolic management of strategic change: Sensegiving via framing and decoupling. Academy of Management Journal, 49(6), 1173-1193.

FRC. (2012). Exposure draft: Guidance on the strategic report. London: Financial Reporting Council.

Frow, P., \& Payne, A. (2011). A stakeholder perspective of the value proposition concept. European Journal of Marketing, 45(1/2), 223-240.

Furnari, S. (2014). Interstitial spaces: Microinteraction settings and the genesis of new practices between institutional fields. Academy of Management Review, 39(4), 439-462.

Gaur, A. S., Delios, A., \& Singh, K. (2007). Institutional environments, staffing strategies, and subsidiary performance. Journal of Management, 33(4), 611-636.

George, G., \& Bock, A. J. (2011). The business model in practice and its implications for entrepreneurship research. Entrepreneurship Theory and Practice, 35(1), 83-111.

Gibson, A., \& Macleod, C. (2012). (Dis) allowances of lesbians' sexual identities: Lesbian identity construction in racialised, classed, familial, and institutional spaces. Feminism \& Psychology, $22(4), 462-481$.

Gioia, D. A., Corley, K. G., \& Hamilton, A. L. (2012). Seeking qualitative rigor in inductive research: Notes on the Gioia Methodology. Organizational Research Methods, 16(1), 15-31.

Glaser, B. G., \& Strauss, A. L. (2012 [1967]). The discovery of grounded theory: Strategies for qualitative research. Piscataway: Transaction Publishers.

Glynn, M. A. (2008). Beyond constraint: How institutions enable identities. In R. Greenwood, C. Oliver, R. Suddaby, \& K. Sahlin-Andersson (Eds.), The Sage handbook of organizational institutionalism (pp. 413-430). Thousand Oaks: Sage.

Gond, J.-P., Cabantous, L., \& Krikorian, F. (2017). How do things become strategic? 'Strategifying' corporate social responsibility. Strategic Organization, [doi.org/10.1177/1476127017702819].

Gordijn, J., Akkermans, H., \& VanVliet, H. (2000). Business modelling is not process modelling Conceptual modeling for e-business and the web (pp. 40-51). Berlin-Heidelberg: Springer.

Grayson, D. (2011). Embedding corporate responsibility and sustainability: Marks \& Spencer. Journal of Management Development, 30(10), 1017 - 1026.

Greenwood, R., Raynard, M., Kodeih, F., Micelotta, E. R., \& Lounsbury, M. (2011). Institutional complexity and organizational responses. The Academy of Management Annals, 5(1), 317371.

Groza, M. D., Pronschinske, M. R., \& Walker, M. (2011). Perceived organizational motives and consumer responses to proactive and reactive CSR. Journal of Business Ethics, 102(4), 639652.

Hahn, T., Pinkse, J., Preuss, L., \& Figge, F. (2015). Tensions in corporate sustainability: Towards an integrative framework. Journal of Business Ethics, 127(2), 297-316.

Hahn, T., Preuss, L., Pinkse, J., \& Figge, F. (2014). Cognitive frames in corporate sustainability: Managerial sensemaking with paradoxical and business case frames. Academy of Management Review, 39(4), 463-487.

Havemo, E. (2018). A visual perspective on value creation: Exploring patterns in business model diagrams. European Management Journal, 36(4), 441-452.

Ioannou, I., \& Serafeim, G. (2015). The impact of corporate social responsibility on investment recommendations: Analysts' perceptions and shifting institutional logics. Strategic Management Journal, 36(7), 1053-1081.

Jamali, D., \& Hossary, M. (2019). CSR Logics in the Middle East. In K. Mellahi \& B. Rettab (Eds.), Practising CSR in the Middle East. Berlin: Springer.

Jamali, D., Lund-Thomsen, P., \& Khara, N. (2015). CSR institutionalized myths in developing countries: An imminent threat of selective decoupling. Business \& Society, 56(3), 454-486. 
Jay, J. (2013). Navigating paradox as a mechanism of change and innovation in hybrid organizations. Academy of Management Journal, 56(1), 137-159.

Jensen, J. C., \& Berg, N. (2012). Determinants of traditional sustainability reporting versus integrated reporting: An institutionalist approach. Business Strategy and the Environment, 21(5), 299316.

Johnson, M. W., Christensen, C. M., \& Kagermann, H. (2008). Reinventing your business model. Harvard Business Review, 86(2), 57-68.

Jones, C., \& Livne-Tarandach, R. Designing a frame: Rhetorical strategies of architectural firms. Journal of organizational behavior, 29(8), 1075-1099.

Jones, G., McLean, C., \& Quattrone, P. (2004). Spacing and timing. Organization, 11(6), 723-741.

Katzenstein, M. F. (1998). Stepsisters: Feminist movement activism in different institutional spaces. In M. Crozat, P. L. Hipsher, M. F. Katzenstein, M. E. Keck, \& B. Klandermans (Eds.), The social movement society: Contentious politics for a new century (pp. 195-216). Lanham: Rowman \& Littlefield

Khurram, S., \& Petit, S. C. (2017). Investigating the dynamics of stakeholder salience: What happens when the institutional change process unfolds? Journal of Business Ethics, 143(3), 485-515.

King, G., Keohane, R. O., \& Verba, S. (1994). Designing social inquiry: Scientific inference in qualitative research. Princeton: Princeton University Press.

King, N., \& Brooks, J. (2017). Template analysis for business and management students. Thousand Oaks: Sage.

Knight, E., Paroutis, S., \& Heracleous, L. (2018). The power of PowerPoint: A visual perspective on meaning making in strategy. Strategic Management Journal, 39(3), 894-921.

Korovkin, T. (2003). Agrarian capitalism and communal institutional spaces. In L. North \& J. D. Cameron (Eds.), Rural progress, rural decay: neoliberal adjustment policies and local initiatives (pp. 127-142). Sterling: Kumarian.

Kostova, T., \& Zaheer, S. (1999). Organizational legitimacy under conditions of complexity: The case of the multinational enterprise. Academy of Management Review, 24(1), 64-81.

Kraatz, M. S., \& Block, E. S. (2008). Organizational implications of institutional pluralism. In R. Greenwood, C. Oliver, R. Suddaby, \& K. Sahlin-Anderson (Eds.), The Sage handbook of organizational institutionalism (pp. 243-275). Thousand Oaks: Sage.

Kubenka, M., \& Myskova, R. (2099). The B2B market: Corporate social responsibility or corporate social responsiveness. WSEAS Transactions on Business and Economics, 7(6), 320-330.

Laasch, O. (2016). Business model change through embedding corporate responsibilitysustainability? Logics, devices, actor networks. (PhD), University of Manchester, Manchester.

Laasch, O. (2018a). An actor-network perspective on business models: How 'Being Responsible' led to incremental, but pervasive change. Long Range Planning, [DOI 10.16/j.lrp.2018.04.002].

Laasch, O. (2018b). Beyond the purely commercial business model: Organizational value logics and the heterogeneity of sustainability business models. Long Range Planning, 51(1), 158-183.

Laasch, O., \& Conaway, R. (2015). Principles of responsible management: Glocal sustainability, responsibility, ethics. Mason: Cengage.

Laasch, O., \& Moosmayer, D. (2015). Competences for responsible management: A structured literature review. CRME Working Papers, l(2).

Laufer, W. S. (2003). Social accountability and corporate greenwashing. Journal of Business Ethics, 43(3), 253-261.

Lawrence, T. B., \& Phillips, N. (2004). From Moby Dick to Free Willy: Macro-cultural discourse and institutional entrepreneurship in emerging institutional fields. Organization, 11(5), 689-711.

Lee, M., \& Battilana, J. (2013). How the zebra got its stripes: Imprinting of individuals and hybrid social ventures. Harvard Business School Working Paper, 14(5).

Lee, M., \& Jay, J. (2015). Strategic responses to hybrid social ventures. California Management Review, 57(3), 126-148.

Leibel, E., Hallett, T., \& Bechky, B. A. (2018). Meaning at the source: The dynamics of field formation in institutional research. Academy of Management annals, 12(1), 154-177. 
Leppelt, T., Foerstl, K., \& Hartmann, E. (2013). Corporate social responsibility in buyer-supplier relationships: Is it beneficial for top-tier suppliers to market their capability to ensure a responsible supply chain? . Business Research, 6(2), 126-152

Lieberman, E. S. (2005). Nested analysis as a mixed-method strategy for comparative research. American Political Science Review, 99(3), 435-452.

Livne-Tarandach, R., Hawbaker, B., Boren, B. L., \& Jones, C. (2015). Qualitative comparative analysis: Opportunities for cross-case research. In K. D. Elsbach \& R. M. Kramer (Eds.), Handbook of qualitative organizational research: Innovative pathways and methods (pp. 156167). New York: Routledge.

Loewenstein, J., Ocasio, W., \& Jones, C. (2012). Vocabularies and vocabulary structure: A new approach linking categories, practices, and institutions. Academy of Management annals, 6(1), 41-86.

Lüdeke-Freund, F., Carroux, S., Joyce, A., Massa, L., \& Breuer, H. (2018). The sustainable business model pattern taxonomy: 45 patterns to support sustainability-oriented business model innovation. Sustainable Production and Consumption, 15, 145-162.

Lund, M. (2013). Innovating a business model for services with storytelling. In C. Emmanouilidis, M. Taisch, \& D. Kiritsis (Eds.), Advances in production management systems: Competitive manufacturing for innovative products and services (pp. 677-684). Berlin Heidelberg: Springer.

Magretta, J. (2002). Why business models matter. Harvard Business Review, 80(5), 86-92.

Mair, J., Mayer, J., \& Lutz, E. (2015). Navigating institutional plurality: Organizational governance in hybrid organizations. Organization Studies, 36(6), 713-739.

Manolova, T. S., Eunni, R. V., \& Gyoshev, B. S. (2008). Institutional environments for entrepreneurship: Evidence from emerging economies in Eastern Europe. Entrepreneurship Theory and Practice, 32(1), 203-218.

Martin, D. B. (2008). E (race) ing race from a national conversation on mathematics teaching and learning: The national mathematics advisory panel as white institutional space. The Mathematics Enthusiast, 5(2), 387-398.

Martin, R., Sunley, P., \& Wills, J. (1994). The decentralization of industrial relations? New institutional spaces and the role of local context in British engineering. Transactions of the Institute of British Geographers, 19(4), 457-481.

Massa, L., Tucci, C., \& Afuah, A. (2017). A critical assessment of business model research. Academy of Management annals, 11(1), 73-104.

McGrath, R. G. (2010). Business models: A discovery driven approach. Long Range Planning, 43(2), 247-261.

Meyer, R. E., \& Höllerer, M. A. (2016). Laying a smoke screen: Ambiguity and neutralization as strategic responses to intra-institutional complexity. Strategic Organization, 14(4), 373-406.

Minor, D., \& Morgan, J. (2011). CSR as reputation insurance: Primum non nocere. California Management Review, 53(3), 40-59.

Misangyi, V. F. (2016). Institutional complexity and the meaning of loose coupling: Connecting institutional sayings and (not) doings. Strategic Organization, 14(4), 407-440.

Mitchell, R. K., Agle, B. R., Chrisman, J. J., \& Spence, L. J. (2011). Toward a theory of stakeholder salience in family firms. Business Ethics Quarterly, 21(2), 235-255.

Mohanty, R. (2004). Institutional dynamics and participatory spaces: The making and unmaking of participation in local forest management in India. ids Bulletin, 35(2), 26-32.

Mohr, J. W., \& Guerra-Pearson, F. (2010). The duality of niche and form: The differentiation of institutional space in New York City, 1888-1917. In M. Lounsbury (Ed.), Categories in markets: Origins and evolution (pp. 321-368). Bingley: Emerald.

Montiel, I. (2008). Corporate social responsibility and corporate sustainability: Separate pasts, common futures. Organization \& Environment, 21(3), 245-269.

Muñoz, P., \& Cohen, B. (2018). A compass for navigating sharing economy business models. California Management Review, 61(1), 114-147.

Naqvi, A. (2015). The Metamorphosis of a Logic: Identifying changing conceptions of CSR in the corporate environment. (PhD), University of Leeds, Leeds. 
Nenonen, S., \& Storbacka, K. (2010). Business model design: Conceptualizing networked value cocreation. International Journal of Quality and Service Sciences, 2(1), 43-59.

Ocasio, W., Loewenstein, J., \& Nigam, A. (2015). How streams of communication reproduce and change institutional logics: The role of categories. Academy of Management Review, 40(1), $28-48$.

Ocasio, W., \& Radoynovska, N. (2016). Strategy and commitments to institutional logics: Organizational heterogeneity in business models and governance. Strategic Organization, 14(4), 287-309.

Ometto, M. P., Gegenhuber, T., Winter, J., \& Greenwood, R. (2018). From balancing missions to mission drift: The role of the institutional context, spaces, and compartmentalization in the scaling of social enterprises. Business \& Society, [10.1177/0007650318758329].

Orsato, R. J. (2006). Competitive environmental strategies: When does it pay to be green? California Management Review, 48(2), 127-143.

Osterwalder, A. (2004). The business model ontology: A proposition in a design science approach. Lausanne: University of Lausanne.

Osterwalder, A., \& Pigneur, Y. (2010). Business model generation. Chichester: Wiley.

Osterwalder, A., Pigneur, Y., Bernarda, G., \& Smith, A. (2014). Value proposition design: How to create products and services customers want. Chichester: Wiley.

Oteman, M., Wiering, M., \& Helderman, J.-K. (2014). The institutional space of community initiatives for renewable energy: A comparative case study of the Netherlands, Germany and Denmark. Energy, sustainability and society, 4(1), 11-28.

Pache, A.-C., \& Santos, F. (2013). Inside the hybrid organization: Selective coupling as response to competing institutional logics. Academy of Management Journal, 56(4), 972-1001.

Pache, A. C., \& Santos, F. (2010). Pache, A. C., \& Santos, F. (2010). When worlds collide: The internal dynamics of organizational responses to conflicting institutional demands. Academy of Management Review, 35(3), 455-476.

Pehlke, T. A., Hennon, C. B., Radina, M. E., \& Kuvalanka, K. A. (2009). Does father still know best? An inductive thematic analysis of popular TV sitcoms. Fathering, 7(2), 114-139.

Perkmann, M. (2018). Protecting scientists from Gordon Gekko: How organizations use hybrid spaces to engage with multiple institutional logics. Organization Science.

Popa, M., \& Salanta, I. (2014). Corporate social responsibility versus corporate social irresponsibility. Management \& Marketing, 9(2), 137-146.

Purdy, J. M., \& Gray, B. (2009). Conflicting logics, mechanisms of diffusion, and multilevel dynamics in emerging institutional fields. Academy of Management Journal, 52(2), 355-380.

Ragin, C. C. (2008). Qualitative comparative analysis using fuzzy sets (fsQCA). In B. Rihoux \& C. C. Ragin (Eds.), Configurational comparative methods (pp. 87-120). Thousand Oaks: Sage.

Randles, S., \& Laasch, O. (2016). Theorising the normative business model (NBM). Organization \& Environment, 29(1), 53-73.

Rauter, R., Jonker, J., \& Baumgartner, R. J. (2017). Going one's own way: Drivers in developing business models for sustainability. Journal of Cleaner Production, 140, 144-154.

Raynard, M. (2016). Deconstructing complexity: Configurations of institutional complexity and structural hybridity. Strategic Organization, 14(4), 310-335.

Raynard, M., Lounsbury, M., \& Greenwood, R. (2013). Legacies of logics: Sources of community variation in CSR implementation in China. In M. Lounsbury \& E. Boxenbaum (Eds.), Institutional logics in action (pp. 243-276). Bingley: Emerald.

Richardson, J. (2008). The business model: An integrative framework for strategy execution. Strategic Change, 17(5-6), 133-144.

Rihoux, B., \& Lobe, B. (2009). The case for qualitative comparative analysis (QCA): Adding leverage for thick cross-case comparison. In D. Byrne \& C. C. Ragin (Eds.), The Sage handbook of case-based methods (pp. 222-242). Thousand Oaks: Sage.

Ritter, T., \& Lettl, C. (2018). The wider implications of business-model research. Long Range Planning, 51(1), 1-8.

Roome, N., \& Louche, C. (2016). Journeying toward business models for sustainability: A conceptual model found inside the black box of organisational transformation. Organization \& Environment, 29(1), 11-35. 
Russo, M. V., \& Fouts, P. A. (1997). A resource-based perspective on corporate environmental performance and profitability. Academy of Management Journal, 40(3), 534-559.

Sage, D., Justesen, L., Dainty, A., Tryggestad, K., \& Mouritsen, J. (2016). Organizing space and time through relational human-animal boundary work: Exclusion, invitation and disturbance. Organization, 23(3), 434-450.

Saldaña, J. (2012). The coding manual for qualitative researchers. Thousand Oaks: Sage.

Santos, F., Pache, A. C., \& Birkholz, C. (2015). Making hybrids work. California Management Review, 57(3), 36-58.

Schildt, H., \& Perkmann, M. (2016). Organizational settlements: Theorizing how organizations respond to institutional complexity. Journal of Management Inquiry, 26(2), 139-145.

Schöneborn, D., \& Trittin, H. (2013). Transcending transmission: Towards a constitutive perspective on CSR communication. Corporate Communications, 18(2), 193-211.

Schultz, F., \& Wehmeier, S. (2010). Institutionalization of corporate social responsibility within corporate communications: Combining institutional, sensemaking and communication perspectives. Corporate Communications, 15(1), 9-29.

Schwartz, M. S., \& Carroll, A. B. (2008). Integrating and unifying competing and complementary frameworks: The search for a common core in the business and society field. Business \& Society, 47(2), 148-186.

Scott, S. G., \& Lane, V. R. (2000). A stakeholder approach to organizational identity. Academy of Management Review, 25(1), 43-62.

Scott, W. R., \& Meyer, J. W. (1994). Institutional environments and organizations: Structural complexity and individualism. Thousand Oaks: Sage.

Seelos, C., \& Mair, J. (2005). Social entrepreneurship: Creating new business models to serve the poor. Business Horizons, 48(3), 241-246.

Seelos, C., \& Mair, J. (2007). Profitable business models and market creation in the context of deep poverty: A strategic view. The Academy of Management Perspectives, 21(4), 49-63.

Setó-Pamies, D., \& Papaoikonomou, E. (2015). A multi-level perspective for the integration of ethics, corporate social responsibility and sustainability (ECSRS) in management education. Journal of Business Ethics, 136(3), 523-538.

Shamir, R. (2008). The age of responsibilization: On market-embedded morality. Economy and Society, 37(1), 1-19.

Sharma, S., \& Vredenburg, H. (1998). Proactive corporate environmental strategy and the development of competitively valuable organizational capabilities. Strategic Management Journal, 19(8), 729-753.

Short, S. W., Rana, P., Bocken, N. M. P., \& Evans, S. (2013). Embedding sustainability in business modelling through multi-stakeholder value innovation. In C. Emmanouilidis, M. Taisch, \& D. Kiritsis (Eds.), Advances in production management systems: Competitive manufacturing for innovative products and services (pp. 175-183). Berlin: Springer.

Smith, W. K., Binns, A., \& Tushman, M. L. (2010). Complex business models: Managing strategic paradoxes simultaneously. Long Range Planning, 43(2), 448-461.

Smith, W. K., \& Tracey, P. (2016). Institutional complexity and paradox theory: Complementarities of competing demands. Strategic Organization, 14(4), 455-466.

Snihur, Y., \& Tarzijan, J. (2018). Managing complexity in a multi-business-model organization. Long Range Planning, 51(1), 50-63.

Sosna, M., Trevnyio-Rodríguez, R. N., \& Velamuri, S. R. (2010). Business model innovation through trial-and-error learning: The Naturhouse case. Long Range Planning, 43(2), 383-407.

Spieth, P., Schneider, S., Clauß, T., \& Eichenberg, D. (2018). Value drivers of social businesses: A business model perspective. Long Range Planning, [https://doi.org/10.1016/j.lrp.2018.04.004].

Stål, H. I., \& Corvellec, H. (2018). A decoupling perspective on circular business model implementation: Illustrations from Swedish apparel. Journal of Cleaner Production, 171, 630-643.

Stevens, R., Moray, N., \& Bruneel, J. (2015). Economic mission of social enterprises: Dimensions, measurement, validation, and relation. Entrepreneurship Theory and Practice, 39(5), 10511082. 
Stubbs, W., \& Cocklin, C. (2008). Conceptualizing a "sustainability business model". Organization \& Environment, 21(2), 103-127.

Suchman, M. C. (1995). Managing legitimacy: Strategic and institutional approaches. Academy of Management Review, 20(3), 571-610.

Suddaby, R., \& Viale, T. (2011). Professionals and field-level change: Institutional work and the professional project. Current Sociology, 59(4), 423-442.

Täuscher, K. (2017). Using qualitative comparative analysis and system dynamics for theory-driven business model research. Strategic Organization, DOI: 1476127017740535.

Teece, D. J. (2010). Business models, business strategy and innovation. Long Range Planning, 43(2), 172-194.

Testa, F., Boiral, O., \& Iraldo, F. (2015). Internalization of environmental practices and institutional complexity: Can stakeholders pressure encourage greenwashing? Journal of Business Ethics [DOI: 10.1007/s10551-015-2960-2].

Thornton, P. H., \& Ocasio, W. (1999). Institutional logics and the historical contingency of power in organizations: Executive succession in the higher education publishing industry, 1958-1990. American Journal of Sociology, 105(3), 801-843.

Torugsa, N. A., O'Donohue, W., \& Hecker, R. (2012). Capabilities, proactive CSR and financial performance in SMEs: Empirical evidence from an Australian manufacturing industry sector. Journal of Business Ethics, 109(4), 483-500.

Vaismoradi, M., Turunen, H., \& Bondas, T. (2013). Content analysis and thematic analysis: Implications for conducting a qualitative descriptive study. Nursing and Health Sciences, 15(1), 398-405.

Van der Byl, C. A., \& Slawinski, N. (2015). Embracing tensions in corporate sustainability: A review of research from win-wins and trade-offs to paradoxes and beyond. Organization \& Environment, 28(1), 54-79.

Van Marrewijk, M. (2003). Concepts and definitions of CSR and corporate sustainability: Between agency and communion. Journal of Business Ethics, 44(2-3), 95-105.

Vermeulen, P., Zietsma, C., \& Greenwood, R. (2014). Special issue of Strategic Organization: "Strategic Responses to institutional complexity". Strategic Organization, 12(1), 79-82.

Wallis, P. J., \& Ison, R. L. (2011). Appreciating institutional complexity in water governance dynamics: A case from the Murray-Darling Basin, Australia. Water Resources Management, 25(15), 4081-4097.

Werther, W. B., \& Chandler, D. (2005). Strategic corporate social responsibility as global brand insurance. Business Horizons, 48(4), 317-324.

Westermann-Behaylo, M., Berman, S. L., \& Van Buren, H. J. (2013). The influence of institutional logics on corporate responsibility toward employees. Business \& Society, 53(5), 714-746.

Yin, J., Singhapakdi, A., \& Du, Y. (2016). Causes and moderators of corporate social responsibility in China: The influence of personal values and institutional logics. Asian Business \& Management, 15(3), 226-254.

Yoon, Y., Gürhan-Canli, Z., \& Schwarz, N. (2006). The effect of corporate social responsibility (CSR) activities on companies with bad reputations. Journal of Consumer Psychology, 16(4), 377-390.

Zietsma, C., \& Lawrence, T. B. (2010). Institutional work in the transformation of an organizational field: The interplay of boundary work and practice work. Administrative Science Quarterly, 55(2), 189-221.

Zott, C., \& Amit, R. (2008). The fit between product market strategy and business model: Implications for firm performance. Strategic Management Journal, 29(1), 1-26.

Zott, C., \& Amit, R. (2010). Business model design: An activity system perspective. Long Range Planning, 43(2), 216-226.

Zott, C., \& Amit, R. (2013). The business model: A theoretically anchored robust construct for strategic analysis. Strategic Organization, 11(4), 403-411.

Zott, C., Amit, R., \& Massa, L. (2011). The business model: Recent developments and future research. Journal of Management, 37(4), 1019-1042. 
Figure 1 Multi-analysis research design

\begin{tabular}{|l|}
\cline { 2 - 2 } \multicolumn{1}{l|}{ Step 1: Responsibility embedding patterns } \\
Empirical material: \\
Mentions of 1512 responsibility elements from 57 \\
business model descriptions \\
Analysis: \\
Thematic analysis, clustering responsibility \\
elements into embedding patterns \\
Results: \\
Description of 15 first-order, and 61 second-order \\
responsibility embedding patterns across value \\
proposition, creation, exchange, capture (Figure 2) \\
\hline
\end{tabular}

Step 2: Business model types across spaces

Empirical material:

Descriptions of corporations' institutional spaces (industry information, news items, CSR reports)

Analysis:

Qualitative-comparative analysis: B2B/B2C, scrutiny no/yes, responsibility embedding no/yes

Results:

Proposition of responsibility embedded BM Types 1-4 and two of non-embedded Types A and B

(Figure 3)
Responsibility BM embedding patterns

\section{Step 3: Unique patterns of BM types}

Empirical material:

Average number of mentions of responsibility pattern per type

Analysis:

Comparing responsibility patterns' intensity across responsibility BM types

Results:

Corroboration of unique responsibility patterns of Types 1-4, corresponding to proposed institutional spaces (Table 1) 
Figure 2 Responsibility-embedding patterns ${ }^{7}$

Value functions
Sub-patterns, exemplary code (Company)*

\section{Main patterns}

\begin{tabular}{|c|c|c|}
\hline \multirow{3}{*}{$\begin{array}{l}\text { Proposition } \\
(294)\end{array}$} & $\begin{array}{l}\text { - Social motivation (27), our Net Positive ambitions... create value for saciety (Kingfisher) } \\
\text { - Stakeholder choice (15), to offer a choice of prochucts across the risk spectrum (BAT) } \\
\text { - Stakeholder interests (49), help our wider stakeholders realise their ambitions (Barclays) }\end{array}$ & Aspirationality (91) \\
\hline & $\begin{array}{l}\text { - Amount of value (38), communities maximum possible value (Nationalgrid) } \\
\text { - Balancing value (12), decisions and actions... balanced, helping to achieve environmental, } \\
\text { social and economic well-being for current and future generations (SSE) }\end{array}$ & Calibration (50) \\
\hline & $\begin{array}{l}\text { - Variety of beneficiaries (95), benefits everyone affected by our actions (Land Securities) } \\
\text { - Products and services (29), specialty care medicines that transform lives (Astra Zeneca) } \\
\text { - Types of value (29), financial benefits for our investors and deliver economic and social } \\
\text { benefits for our customers, employees and societies in which we operate (Prudential) }\end{array}$ & $\begin{array}{c}\text { Elements of } \\
\text { proposition (153) }\end{array}$ \\
\hline \multirow{5}{*}{$\begin{array}{l}\text { Creation } \\
(356)\end{array}$} & $\begin{array}{l}\text { - Responsible operations (35), operating responsibly (Capita) } \\
\text {-(Eco)Efficiency (21), environmentally efficient distribution centres (Morrisons) } \\
\text { - Social issues in operations (36), health and safety, ... across our operations (G4S) }\end{array}$ & Operationality (92) \\
\hline & $\begin{array}{l}\text { - 'Good' business approach (33), business a sustainable \& responsible way (Diageo) } \\
\text { - Responsible decision making (18), Plan A affects every decision we make (M\&S) } \\
\text { - Responsible behavior (43), safety wnderpins everything we do (Easyjet) }\end{array}$ & $\begin{array}{c}\text { Decisions and } \\
\text { actions (94) }\end{array}$ \\
\hline & $\begin{array}{l}\text { - Integrated in culture (17), integrating these values into our culture (GSK) } \\
\text { - Integrated across business (18), initiatives across the divisions ... responsibility and } \\
\text { accountability (Smiths Group) }\end{array}$ & $\begin{array}{c}\text { Integrating } \\
\text { responsibility (35) }\end{array}$ \\
\hline & $\begin{array}{l}\text { - Responsible workplace (26), responsibility ... a special place to work (Legal \& General) } \\
\text { - Managerial responsibility (11), managers dedicated to sustainability (Fresnillo) } \\
\text { - Values (19), guided by ... values of sustainability; integrity; ... accountability (BHP Billiton) }\end{array}$ & Human actors (56) \\
\hline & $\begin{array}{l}\text { - Governance of responsibility (25), governance ... of responsibility (Imperial Tobacco) } \\
\text { - Organizational (infra)structure (14), our ... fleet is diverse and low carbon (Centrica) } \\
\text { - Resources (15), allocate resources ... in the best interests of... stakeholders (Shire) } \\
\text { - Corporate responsibility Programs (17), Community programmes, sport and active } \\
\text { lifestyles, youth development, water stewardship, disaster relief (Coca Cola HBC) }\end{array}$ & Structures (71) \\
\hline \multirow{4}{*}{$\begin{array}{l}\text { Exchange } \\
(496)\end{array}$} & $\begin{array}{l}\text { - Relationships (21), long-term relationships with host governments ... the communities and the } \\
\text { enviromments we work within (Tullow) } \\
\text { - Relational qualities (46), respectful, mutually beneficial stakeholder relationships (Anglo } \\
\text { American) } \\
\text { - Relational hubs (24), our centres' role as vital hubs for the community (Intu) } \\
\text { - Culture (8), shaping our culture as we embrace diversity (Mondi) } \\
\text { - Reputation \& brand (6), positive contribution to the communities... protecting the } \\
\text { reputation of our brands (Intercontinental Hotels) }\end{array}$ & \multirow[t]{2}{*}{ Relationality (105) } \\
\hline & $\begin{array}{l}\text { - Making connections (27), foster relations hips with local authorities ... so we can ... benefit } \\
\text { local communities (Land Securities) } \\
\text { - Dialogue (21), mutually respectful relations through contimuous dialogue (Fresnillo) } \\
\text { - Providing benefits (43), benefits for the communities in which we operate (Rio Tinto) } \\
\text { - Develoning \& enabling (3) }\end{array}$ & \\
\hline & $\begin{array}{l}\text { - Developing \& enabling (36), helping people ... progress in their lives (Pearson) } \\
\text { - Engagement (18), iterative process of community engagement (Taylor Wimpey) } \\
\text { - Instrumental relationships (14), a positive contribution to the communities ... gives us } \\
\text { competitive advantage by enhancing.... the reputation of our brands (Intercontinental Hotels) } \\
\text { - Cocreation \& partnership (34), creating ... long-term partnerships (SAB Miller) } \\
\text { - Material exchange (25), waste diverted from landfill (Whitbread) } \\
\text { - Contractual-transactional relationship (13), settling claims fairly (RSA Insurance) }\end{array}$ & $\begin{array}{l}\text { Modes of exchange } \\
(231)\end{array}$ \\
\hline & $\begin{array}{l}\text { - Stakeholders (14), value for all our stakeholders (Capita) } \\
\text { - Community (26), relationships we form with ... community groups are vital (Old Mutual) } \\
\text { - Customers (22), rebuild the trust of our customers (Lloyds) } \\
\text { - Employees (14), managing responsibly interaction with ... our employees (United Utilities) } \\
\text { - Government \& regulators (14), supporting regulation (British American Tobacco) } \\
\text { - Shareholders (6), our business model delivers value to shareholders (British Telecom) } \\
\text { - Society (6), helping Britain prosper (Lloyds) } \\
\text { - Suppliers \& partners (14), buy from ... ethically responsible manufacturers (Travisperkins) } \\
\text { - (Local) environment (13), protect ... the places in which we operate (British Petroleum) }\end{array}$ & $\begin{array}{c}\text { Exchange } \\
\text { counterparts (150) }\end{array}$ \\
\hline
\end{tabular}

${ }^{7}$ Numbers in parentheses express the total frequency with which each pattern was observed among FTSE100 


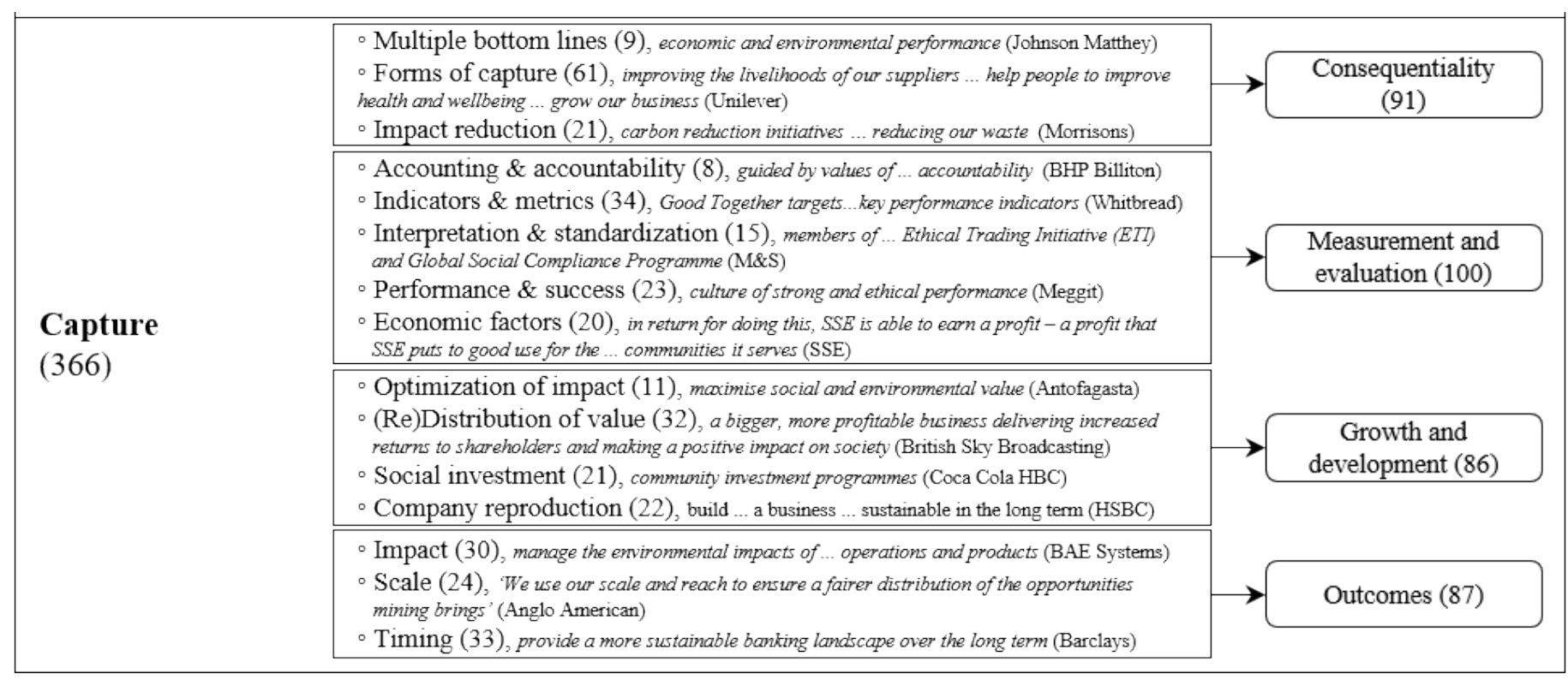


Figure 3 Explanatory framework of strategic responses across spaces of institutional complexity shaping business model types

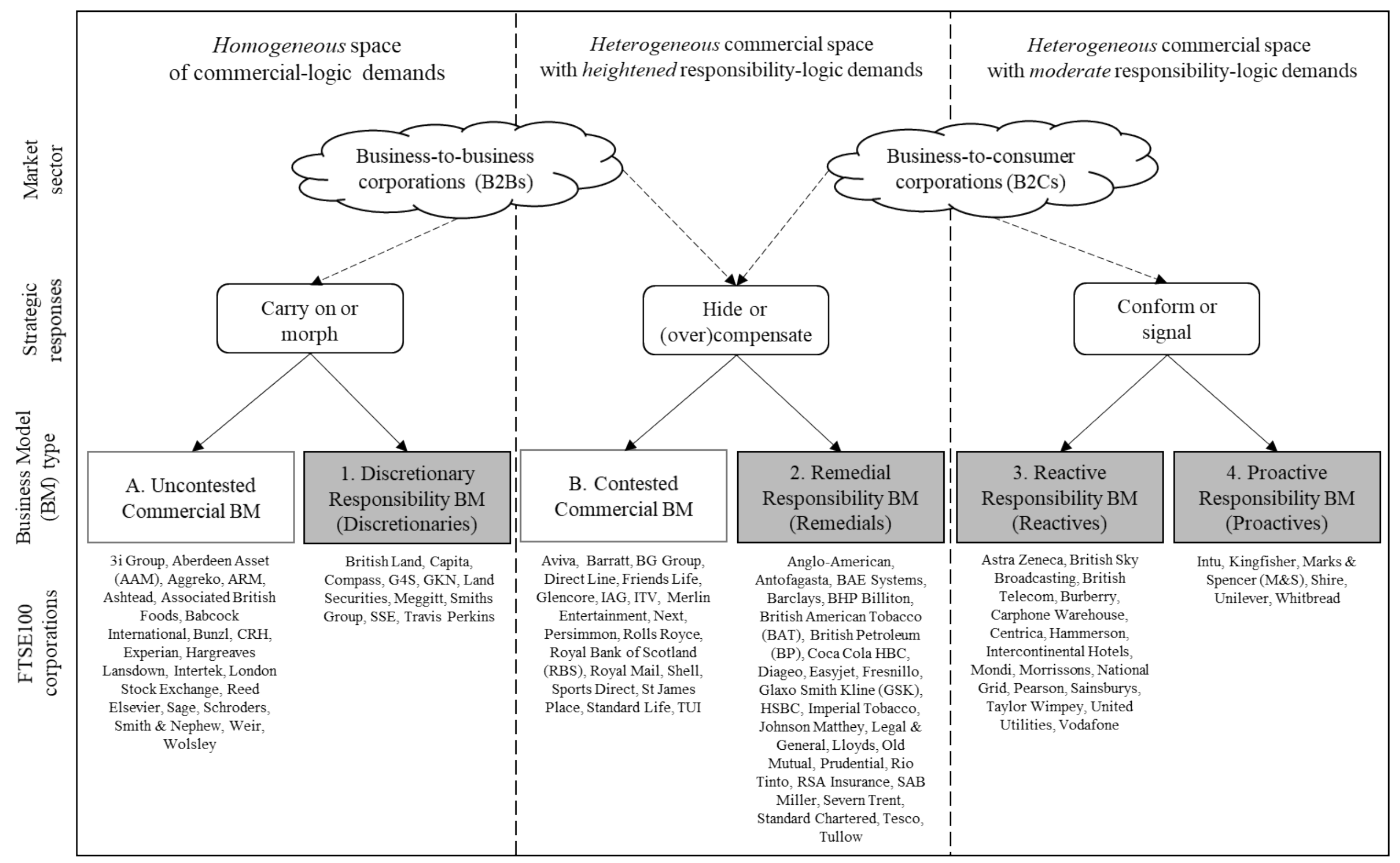


Table 1 Distinctive embedding patterns of responsibility business model types*

\begin{tabular}{|c|c|c|c|c|}
\hline & 1. Discretionaries & 2. Remedials & 3. Reactives & 4. Proactives \\
\hline \multirow{3}{*}{ 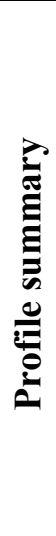 } & $\begin{array}{l}\text { Average frequency of } \\
\text { responsibility element } \\
\text { mentions: } 17.7\end{array}$ & $\begin{array}{l}\text { Average frequency } \\
\text { of responsibility } \\
\text { element mentions: } \\
29.4\end{array}$ & $\begin{array}{l}\text { Average frequency of } \\
\text { responsibility element } \\
\text { mentions: } 22.1\end{array}$ & $\begin{array}{l}\text { Average frequency of } \\
\text { responsibility element } \\
\text { mentions: } 36.2\end{array}$ \\
\hline & $\begin{array}{l}\text { Morphing } \\
\text { responsibility into a } \\
\text { commercial factor to } \\
\text { respond to } \\
\text { homogeneous } \\
\text { commercial demands }\end{array}$ & $\begin{array}{l}29.4 \\
\text { Overcompensating } \\
\text { transgressions } \\
\text { through wide and } \\
\text { intensive } \\
\text { responsibility } \\
\text { embedding }\end{array}$ & \multirow{2}{*}{$\begin{array}{l}\text { Conforming to } \\
\text { moderate } \\
\text { responsibility } \\
\text { demands by wide, but } \\
\text { non-intensive } \\
\text { responsibility } \\
\text { embedding } \\
\text { (16 corporations) }\end{array}$} & \multirow{2}{*}{$\begin{array}{l}\text { Signalling } \\
\text { responsibility by } \\
\text { highlighting } \\
\text { differentiated } \\
\text { intensive } \\
\text { responsibility } \\
\text { embedding } \\
\text { ( } 6 \text { corporations) }\end{array}$} \\
\hline & & (26 corporations) & & \\
\hline \multirow{3}{*}{ : } & $\begin{array}{l}\text {-Lowest of all types in } \\
\text { intrinsic social } \\
\text { motivation (4) }\end{array}$ & \multirow{3}{*}{$\begin{array}{l}\text {-Offsetting past } \\
\text { digressions through } \\
\text { high intensity }(1) \\
\text { embedding into value } \\
\text { proposition with } \\
\text { wide variety of } \\
\text { recipients and types } \\
\text { of value proposed } \\
(11,13)\end{array}$} & \multirow{3}{*}{$\begin{array}{l}\text {-Low-intensity } \\
\text { coverage of most } \\
\text { elements of a } \\
\text { responsibility value } \\
\text { proposition (5-13) }\end{array}$} & \multirow{3}{*}{$\begin{array}{l}\text {-Value proposition } \\
\text { tackling grand } \\
\text { societal and } \\
\text { environmental issues } \\
(59,61) \text { out of } \\
\text { intrinsic social } \\
\text { motivation }(4,5) \\
\text {-Well-calibrated (7-9) } \\
\text { responsibility in } \\
\text { products and services } \\
(12)\end{array}$} \\
\hline & $\begin{array}{l}\text {-Lowest intensity of } \\
\text { embedding into value } \\
\text { proposition (2) and } \\
\text { least intensity across }\end{array}$ & & & \\
\hline & $\begin{array}{l}\text { value proposition } \\
\text { patterns }(3-13)\end{array}$ & & & \\
\hline \multirow{3}{*}{ : } & $\begin{array}{l}\text {-Emphasis of social } \\
\text { issues in operations, } \\
\text { and eco-efficiency ( } 17 \text {, } \\
18)\end{array}$ & $\begin{array}{l}\text {-Role of employees } \\
(56) \text {, and their values } \\
\text { (29) for a responsible } \\
\text { workplace (27) }\end{array}$ & \multirow{3}{*}{$\begin{array}{l}\text {-Superficial } \\
\text { embedding into value } \\
\text { creation }(14) \text { with no } \\
\text { embedding into areas } \\
\text { that would require a } \\
\text { greater commitment } \\
(14,30,34) .\end{array}$} & \multirow{3}{*}{$\begin{array}{l}\text {-Differentiation } \\
\text { through company- } \\
\text { wide responsibility } \\
\text { programmes tackling } \\
\text { multiple issues (34) } \\
\text {-De-emphasis of } \\
\text { basic, operational } \\
\text { responsibility aspects } \\
\text { (15-18), subsumed } \\
\text { under a good business } \\
\text { approach (19) of } \\
\text { integrating } \\
\text { responsibility (23-25) } \\
\text { and by transforming } \\
\text { structures }(30,33)\end{array}$} \\
\hline & $\begin{array}{l}\text {-Wide integration of } \\
\text { responsibility into } \\
\text { commercial operations }\end{array}$ & $\begin{array}{l}\text {-Role of managers } \\
\text { (28) in governance of } \\
\text { responsibility (31) }\end{array}$ & & \\
\hline & $\begin{array}{l}(23-23) \\
\text {-Leading in } \\
\text { responsible behaviour } \\
(22) \text { and responsible } \\
\text { governance (31) }\end{array}$ & $\begin{array}{l}\text {-Responsible } \\
\text { operations (16) } \\
\text { focussing on eco- } \\
\text { efficiency (17) and } \\
\text { social issues in } \\
\text { operations (18) }\end{array}$ & & \\
\hline \multirow{3}{*}{ 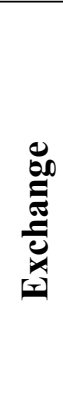 } & \multirow[t]{3}{*}{$\begin{array}{l}\text {-Commercial } \\
\text { stakeholders primacy } \\
(53,56,57,58,60)\end{array}$} & $\begin{array}{l}\text {-Highest intensity of } \\
\text { responsibility in } \\
\text { value exchange (35) }\end{array}$ & \multirow{3}{*}{$\begin{array}{l}\text {-Lowest intensity of } \\
\text { involving key } \\
\text { commercial } \\
\text { stakeholders }(60,56 \text {, } \\
57)\end{array}$} & \multirow{3}{*}{$\begin{array}{l}\text {-Focus on key } \\
\text { instrumental } \\
\text { relationships for co- } \\
\text { creation }(37,48,55, \\
60,49) \\
\text {-Covering wider } \\
\text { stakeholder } \\
\text { relationships through } \\
\text { relational hubs (39) }\end{array}$} \\
\hline & & $\begin{array}{l}\text {-Wide variety of } \\
\text { modes of exchange }\end{array}$ & & \\
\hline & & $\begin{array}{l}\text { (42), but do not } \\
\text { search too close } \\
\text { engagement with } \\
\text { single groups ( } 47)\end{array}$ & & \\
\hline
\end{tabular}




\begin{tabular}{|c|c|c|c|c|}
\hline 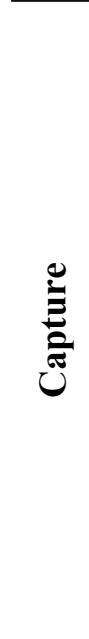 & $\begin{array}{l}\text {-Emphasis on } \\
\text { embedding } \\
\text { responsibility links to } \\
\text { performance and } \\
\text { success ( } 71) \\
\text {-Focus on } \\
\text { responsibility } \\
\text { standards linked to } \\
\text { employee productivity } \\
(70)\end{array}$ & $\begin{array}{l}\text {-Wide embedding in } \\
\text { value capture, } \\
\text { covering all main } \\
\text { elements (62-81) } \\
\text {-Focus on capturing } \\
\text { value across multiple } \\
\text { bottom lines (64) }\end{array}$ & $\begin{array}{l}\text {-Low-intensity, but } \\
\text { wide coverage of } \\
\text { responsibility capture } \\
(67-72) \text {, but neglecting } \\
\text { social impact (79) and } \\
\text { the longevity of } \\
\text { responsibility } \\
\text { initiatives (81) } \\
\text {-Last in linking } \\
\text { responsibility to } \\
\text { economic factors (72) } \\
\text { and few instrumental } \\
\text { relationships (48) }\end{array}$ & $\begin{array}{l}\text {-Emphasis of each } \\
\text { company's } \\
\text { differentiated } \\
\text { responsibility capture } \\
\text { measures }(64,65,66 \text {, } \\
69 \text { ) } \\
\text {-Capture entangled } \\
\text { with commercial } \\
\text { dimension }(41,72) \text {, } \\
\text { leading to concerns } \\
\text { for long-run } \\
\text { responsibility } \\
\text { outcomes, impacts, } \\
\text { and scale (72-81) }\end{array}$ \\
\hline
\end{tabular}

*Numbers in parentheses refer to the respective lines of Appendix Table A. 2 for further reference 


\section{APPENDICES}

Table A. 1 Comparative analysis table

\begin{tabular}{|c|c|c|c|c|c|c|c|c|c|c|}
\hline \multirow[t]{2}{*}{ Company } & \multirow[t]{2}{*}{ Industry } & \multirow[t]{2}{*}{ Company scandal/ Industry scrutiny } & \multicolumn{2}{|c|}{ 1.Sector } & \multicolumn{2}{|c|}{ 2.Scrutiny } & \multirow[t]{2}{*}{$\rightarrow$ Space } & \multicolumn{2}{|c|}{ 3.Res-BM } & \multirow[t]{2}{*}{ Notes } \\
\hline & & & $\mathrm{B} 2 \mathrm{~B}$ & $\mathrm{~B} 2 \mathrm{C}$ & No & Yes & & No & Yes & \\
\hline \multicolumn{11}{|c|}{ A. Uncontested Commercial Business Models (Uncontesteds) } \\
\hline 3i Group & Financial Services & & $\mathrm{x}$ & o & $\mathrm{x}$ & o & Com & $\mathrm{x}$ & $\mathrm{o}$ & \\
\hline Aberdeen Asset (AAM) & Financial Services & & $\mathrm{x}$ & $\mathrm{o}$ & $\mathrm{x}$ & $\mathrm{o}$ & Com & $\mathrm{x}$ & $\mathrm{o}$ & \\
\hline Aggreko & General Industrials & & $\mathrm{x}$ & $\mathrm{o}$ & $\mathrm{x}$ & $\mathrm{o}$ & Com & $\mathrm{x}$ & $\mathrm{o}$ & \\
\hline ARM & General Industrials & & $\mathrm{x}$ & $\mathrm{o}$ & $\mathrm{x}$ & o & Com & $\mathrm{x}$ & $\mathrm{o}$ & \\
\hline Ashtead & Support Services & & $\mathrm{x}$ & $\mathrm{o}$ & $\mathrm{x}$ & $\mathrm{o}$ & Com & $\mathrm{x}$ & $\mathrm{o}$ & \\
\hline Associated British Foods & Food Producers & & $\mathrm{x}$ & $\mathrm{o}$ & $\mathrm{x}$ & $\mathrm{o}$ & Com & $\mathrm{x}$ & $\mathrm{o}$ & \\
\hline Babcock International & Support Services & & $\mathrm{x}$ & $\mathrm{o}$ & $\mathrm{x}$ & o & Com & $\mathrm{x}$ & $\mathrm{o}$ & \\
\hline Bunzl & Support Services & & $\mathrm{x}$ & o & $\mathrm{x}$ & o & Com & $\mathrm{x}$ & $\mathrm{o}$ & \\
\hline CRH & Construct. \& Materials & & $\mathrm{x}$ & $\mathrm{o}$ & $\mathrm{x}$ & $\mathrm{o}$ & Com & $\mathrm{x}$ & 0 & \\
\hline Experian & Support Services & & $\mathrm{x}$ & $\mathrm{o}$ & $\mathrm{x}$ & $\mathrm{o}$ & Com & $\mathrm{x}$ & $\mathrm{o}$ & \\
\hline Hargreaves Lansdown & Financial Services & & $\mathrm{x}$ & $\mathrm{o}$ & $\mathrm{x}$ & o & Com & $\mathrm{x}$ & $\mathrm{o}$ & \\
\hline Intertek & Support Services & & $\mathrm{x}$ & $\mathrm{o}$ & $\mathrm{x}$ & $\mathrm{o}$ & Com & $\mathrm{x}$ & $\mathrm{o}$ & \\
\hline London Stock Exchange & Financial Services & & $\mathrm{x}$ & $\mathrm{o}$ & $\mathrm{x}$ & $\mathrm{o}$ & Com & $\mathrm{x}$ & $\mathrm{o}$ & \\
\hline Reed Elsevier & Media & & $\mathrm{x}$ & o & $\mathrm{x}$ & o & Com & $\mathrm{x}$ & $\mathrm{o}$ & \\
\hline Sage & Software Services & & $\mathrm{x}$ & $\mathrm{o}$ & $\mathrm{x}$ & $\mathrm{o}$ & Com & $\mathrm{x}$ & $\mathrm{o}$ & \\
\hline Schroders & Financial Services & & $\mathrm{x}$ & $\mathrm{o}$ & $\mathrm{x}$ & $\mathrm{o}$ & Com & $\mathrm{x}$ & $\mathrm{o}$ & \\
\hline Smith \& Nephew & General Industrials & & $\mathrm{x}$ & o & $\mathrm{x}$ & o & Com & $\mathrm{x}$ & $\mathrm{o}$ & \\
\hline Weir & Support Services & & $\mathrm{x}$ & o & $\mathrm{x}$ & o & Com & $\mathrm{x}$ & $\mathrm{o}$ & \\
\hline Wolsley & Construction \& Material & & $\mathrm{x}$ & 0 & $\mathrm{x}$ & $\mathrm{o}$ & Com & $\mathrm{x}$ & $\mathrm{o}$ & \\
\hline \multicolumn{11}{|c|}{ 1. Discretionary Responsibility Business Models (Discretionaries) } \\
\hline British Land & Real Estate Inv. Trusts & & $\mathrm{x}$ & $\mathrm{o}$ & $\mathrm{x}$ & $\mathrm{o}$ & Com & $\mathrm{o}$ & $\mathrm{x}$ & \\
\hline Capita & Support Services & & $\mathrm{x}$ & $\mathrm{o}$ & $\mathrm{x}$ & $\mathrm{o}$ & Com & $\mathrm{o}$ & $\mathrm{x}$ & \\
\hline Compass & Support Services & & $\mathrm{x}$ & o & $\mathrm{x}$ & o & Com & o & $\mathrm{x}$ & \\
\hline G4S & Support Services & & $\mathrm{x}$ & $\mathrm{o}$ & $\mathrm{x}$ & o & Com & $\mathrm{o}$ & $\mathrm{x}$ & \\
\hline GKN & Automobiles \& Parts & & $\mathrm{x}$ & $\mathrm{o}$ & $\mathrm{x}$ & $\mathrm{o}$ & Com & $\mathrm{o}$ & $\mathrm{x}$ & \\
\hline Land Securities & Real Estate Investm. Trusts & & $\mathrm{x}$ & $\mathrm{o}$ & $\mathrm{x}$ & $\mathrm{o}$ & Com & $\mathrm{o}$ & $\mathrm{x}$ & \\
\hline Meggitt & General Industrials & & $\mathrm{x}$ & $\mathrm{o}$ & $\mathrm{x}$ & $\mathrm{o}$ & Com & $\mathrm{o}$ & $\mathrm{x}$ & \\
\hline Smiths Group & General Industrials & & $\mathrm{x}$ & $\mathrm{o}$ & $\mathrm{x}$ & $\mathrm{o}$ & Com & o & $\mathrm{x}$ & \\
\hline SSE & Electricity & & $\mathrm{x}$ & $\mathrm{o}$ & $\mathrm{x}$ & o & Com & o & $\mathrm{x}$ & \\
\hline Travis Perkins & Construct. \& Materials & & $\mathrm{x}$ & $\mathrm{o}$ & $\mathrm{x}$ & $\mathrm{o}$ & Com & $\mathrm{o}$ & $\mathrm{x}$ & \\
\hline
\end{tabular}




\begin{tabular}{|c|c|c|c|c|c|c|c|c|c|c|}
\hline \multicolumn{11}{|c|}{ B. Contested Commercial Business Models (Contesteds) } \\
\hline Aviva & Life Insurance & /Insurance bankruptcies, claims settling issues & $\mathrm{o}$ & $\mathrm{x}$ & o & $\mathrm{x}$ & Com/Resp+ & $\mathrm{x}$ & o & \\
\hline Barratt & Home Construct. & & o & $\mathrm{x}$ & $\mathrm{x}$ & o & Com/Resp+ & $\mathrm{x}$ & o & Outlier $^{8}$ \\
\hline BG Group & Oil \& Gas Producers & Fossil fuels and climate change & $\mathrm{x}$ & o & o & $\mathrm{x}$ & Com/Resp+ + & $\mathrm{x}$ & $\mathrm{o}$ & \\
\hline Direct Line & Nonlife Insurance & Falsified claims (2012)/ Insurance bankruptcies, claims settling & $\mathrm{o}$ & $\mathrm{x}$ & o & $\mathrm{x}$ & Com/Resp+ & $\mathrm{x}$ & o & \\
\hline Friends Life & Life Insurance & /Insurance bankruptcies, claims settling issues & $\mathrm{o}$ & $\mathrm{x}$ & o & $\mathrm{x}$ & Com/Resp+ & $\mathrm{x}$ & o & \\
\hline Glencore & Mining & /Dangerous \& harmful for environment & $\mathrm{x}$ & o & o & $\mathrm{x}$ & Com/Resp+ & $\mathrm{x}$ & o & \\
\hline IAG & Travel \& Leisure & /Air travel safety, $\mathrm{CO} 2$ impact of flying & o & $\mathrm{x}$ & o & $\mathrm{x}$ & Com/Resp+ & $\mathrm{x}$ & o & \\
\hline ITV & Media & & $\mathrm{o}$ & $\mathrm{x}$ & $\mathrm{x}$ & o & Com/Resp+ & $\mathrm{x}$ & $\mathrm{o}$ & Outlier $^{7}$ \\
\hline Merlin Entertainment & Travel \& Leisure & /Poor customer records \& environmental impact & o & $\mathrm{x}$ & o & $\mathrm{x}$ & Com/Resp+ & $\mathrm{x}$ & o & \\
\hline Next & General Retailers & Below-living-wages (2014)/ & $\mathrm{o}$ & $\mathrm{x}$ & o & $\mathrm{x}$ & Com/Resp+ + & $\mathrm{x}$ & $\mathrm{o}$ & \\
\hline Persimmon & Home Construct. & Building botch and safety $(2013,2014) /$ & $\mathrm{o}$ & $\mathrm{x}$ & o & $\mathrm{x}$ & Com/Resp + & $\mathrm{x}$ & $\mathrm{o}$ & \\
\hline Rolls Royce & Aerospace \& Defense & /Role in equipping armed conflicts & $\mathrm{o}$ & $\mathrm{x}$ & o & $\mathrm{x}$ & Com/Resp+ + & $\mathrm{x}$ & $\mathrm{o}$ & \\
\hline Royal Bank of Scotland (RBS) & Banks & /Global financial crisis & $\mathrm{o}$ & $\mathrm{x}$ & o & $\mathrm{x}$ & Com/Resp+ & $\mathrm{x}$ & o & \\
\hline Royal Mail & Industrial Transport & Privatization, fraudulent undervaluing (2013)/ & $\mathrm{o}$ & $\mathrm{x}$ & o & $\mathrm{x}$ & Com/Resp+ & $\mathrm{x}$ & o & \\
\hline Shell & Oil \& Gas Producers & /Fossil fuels and climate change & $\mathrm{o}$ & $\mathrm{x}$ & $\mathrm{o}$ & $\mathrm{x}$ & Com/Resp + & $\mathrm{x}$ & $\mathrm{o}$ & \\
\hline Sports Direct & General Retailers & Zero-hour contracts (2013)/ & 0 & $\mathrm{x}$ & o & $\mathrm{x}$ & Com/Resp+ & $\mathrm{x}$ & $\mathrm{o}$ & \\
\hline St James Place & Life Insurance & /Insurance bankruptcies, claims settling issues & $\mathrm{o}$ & $\mathrm{x}$ & o & $\mathrm{x}$ & Com/Resp+ & $\mathrm{x}$ & $\mathrm{o}$ & \\
\hline Standard Life & Life Insurance & /Insurance bankruptcies, claims settling issues & o & $\mathrm{x}$ & o & $\mathrm{x}$ & Com/Resp+ & $\mathrm{x}$ & o & \\
\hline TUI & Travel \& Leisure & /Poor customer records \& environmental impact & $\mathrm{o}$ & $\mathrm{x}$ & o & $\mathrm{x}$ & Com/Resp+ & $\mathrm{x}$ & o & \\
\hline \multicolumn{11}{|c|}{ 2. Remedial Responsibility Business Models (Remedials) } \\
\hline Anglo-American & Mining & /Dangerous \& harmful for environment & $\mathrm{x}$ & o & o & $\mathrm{x}$ & Com/Resp+ & o & $\mathrm{x}$ & \\
\hline Antofagasta & Mining & /Dangerous \& harmful for environment & $\mathrm{x}$ & o & o & $\mathrm{x}$ & Com/Resp+ & o & $\mathrm{x}$ & \\
\hline BAE Systems & Aerospace \& Defense & /Role in equipping armed conflicts & $\mathrm{x}$ & o & o & $\mathrm{x}$ & Com/Resp+ & o & $\mathrm{x}$ & \\
\hline Barclays & Banks & /Global financial crisis & $\mathrm{o}$ & $\mathrm{x}$ & o & $\mathrm{x}$ & Com/Resp+ & o & $\mathrm{x}$ & \\
\hline BHP Billiton & Mining & /Dangerous \& harmful for environment & $\mathrm{x}$ & o & o & $\mathrm{x}$ & Com/Resp+ & o & $\mathrm{x}$ & \\
\hline British American Tobacco (BAT) & Tobacco & /Health hazard tobacco & o & $\mathrm{x}$ & o & $\mathrm{x}$ & Com/Resp+ & o & $\mathrm{x}$ & \\
\hline British Petroleum (BP) & Oil \& Gas Producers & /Fossil fuels and climate change & $\mathrm{o}$ & $\mathrm{x}$ & o & $\mathrm{x}$ & Com/Resp+ & o & $\mathrm{x}$ & \\
\hline Coca Cola HBC & Beveridges & /Unhealthy \& addictive (alcohol, sugar) & o & $\mathrm{x}$ & o & $\mathrm{x}$ & Com/Resp+ & o & $\mathrm{x}$ & \\
\hline Diageo & Beveridges & /Unhealthy \& addictive (alcohol, sugar) & o & $\mathrm{x}$ & o & $\mathrm{x}$ & Com/Resp+ & o & $\mathrm{x}$ & \\
\hline Easyjet & Travel \& Leisure & /Air travel safety, $\mathrm{CO} 2$ impact of flying & $\mathrm{o}$ & $\mathrm{x}$ & o & $\mathrm{x}$ & Com/Resp+ & o & $\mathrm{x}$ & \\
\hline Fresnillo & Mining & /Dangerous \& harmful for environment & $\mathrm{x}$ & $\mathrm{o}$ & o & $\mathrm{x}$ & Com/Resp+ & $\mathrm{o}$ & $\mathrm{x}$ & \\
\hline Glaxo Smith Kline (GSK) & Pharma \& Biotech & Healthcare fraud, bribing doctors (2012)/ & $\mathrm{o}$ & $\mathrm{x}$ & o & $\mathrm{x}$ & Com/Resp+ & o & $\mathrm{x}$ & \\
\hline HSBC & Banks & /Global financial crisis & $\mathrm{o}$ & $\mathrm{x}$ & o & $\mathrm{x}$ & Com/Resp+ & o & $\mathrm{x}$ & \\
\hline Imperial Tobacco & Tobacco & /Health hazard tobacco & $\mathrm{o}$ & $\mathrm{x}$ & o & $\mathrm{x}$ & Com/Resp+ & o & $\mathrm{x}$ & \\
\hline Johnson Matthey & Chemicals & /Chemicals' hazards for environment and health & $\mathrm{x}$ & o & o & $\mathrm{x}$ & Com/Resp+ & o & $\mathrm{x}$ & \\
\hline Legal \& General & Life Insurance & /Insurance bankruptcies, claims settling issues & $\mathrm{o}$ & $\mathrm{x}$ & o & $\mathrm{x}$ & Com/Resp+ + & o & $\mathrm{x}$ & \\
\hline Lloyds & Banks & /Global financial crisis & o & $\mathrm{x}$ & o & $\mathrm{x}$ & Com/Resp+ & o & $\mathrm{x}$ & \\
\hline
\end{tabular}

${ }^{8}$ Barrat and ITV are outliers as they only imperfectly fit the Uncontesteds classification (no scandal no industry scrutiny). 


\begin{tabular}{|c|c|c|c|c|c|c|c|c|c|c|}
\hline Old Mutual & Life Insurance & /Insurance bankruptcies, claims settling & $\mathrm{o}$ & $\mathrm{x}$ & o & $\mathrm{x}$ & Com/Resp+ & o & $\mathrm{x}$ & \\
\hline Prudential & Life Insurance & /Insurance bankruptcies, claims settling issues & $\mathrm{o}$ & $\mathrm{x}$ & $\mathrm{o}$ & $\mathrm{x}$ & Com/Resp+ & $\mathrm{o}$ & $\mathrm{x}$ & \\
\hline Rio Tinto & Mining & /Dangerous \& harmful for environment & $\mathrm{x}$ & $\mathrm{o}$ & $\mathrm{o}$ & $\mathrm{x}$ & Com/Resp+ & $\mathrm{o}$ & $\mathrm{x}$ & \\
\hline RSA Insurance & Nonlife Insurance & /Insurance bankruptcies, claims settling issues & $\mathrm{o}$ & $\mathrm{x}$ & $\mathrm{o}$ & $\mathrm{x}$ & Com/Resp+ & o & $\mathrm{x}$ & \\
\hline SAB Miller & Beveridges & /Unhealthy \& addictive (alcohol, sugar) & $\mathrm{o}$ & $\mathrm{x}$ & o & $\mathrm{x}$ & Com/Resp ${ }^{+}$ & $\mathrm{o}$ & $\mathrm{x}$ & \\
\hline Severn Trent & Gas, Water \& Utilities & Overcharging fraud (2012)/ & $\mathrm{o}$ & $\mathrm{x}$ & $\mathrm{o}$ & $\mathrm{x}$ & Com/Resp+ & $\mathrm{o}$ & $\mathrm{x}$ & \\
\hline Standard Chartered & Banks & /Global financial crisis & o & $\mathrm{x}$ & o & $\mathrm{x}$ & Com/Resp+ & o & $\mathrm{x}$ & \\
\hline Tesco & Food/ Drug Retailers & Horsemeat (2013)/ & $\mathrm{o}$ & $\mathrm{x}$ & $\mathrm{o}$ & $\mathrm{x}$ & Com/Resp + & $\mathrm{o}$ & $\mathrm{x}$ & \\
\hline Tullow & Oil \& Gas Producers & /Fossil fuels and climate change & $\mathrm{x}$ & $\mathrm{o}$ & $\mathrm{o}$ & $\mathrm{x}$ & Com/Resp+ & o & $\mathrm{x}$ & \\
\hline \multicolumn{11}{|c|}{ 3. Reactive Responsibility Business Models (Reactives) } \\
\hline Astra Zeneca & Pharma \& Biotech & & $\mathrm{o}$ & $\mathrm{x}$ & $\mathrm{x}$ & o & Com/Resp- & o & $\mathrm{x}$ & \\
\hline British Sky Broadcasting & Media & & $\mathrm{o}$ & $\mathrm{x}$ & $\mathrm{x}$ & 0 & Com/Resp- & $\mathrm{o}$ & $\mathrm{x}$ & \\
\hline British Telecom & Telecommunications & & o & $\mathrm{x}$ & $\mathrm{x}$ & $\mathrm{o}$ & Com/Resp- & $\mathrm{o}$ & $\mathrm{x}$ & \\
\hline Burberry & Personal Goods & & $\mathrm{o}$ & $\mathrm{x}$ & $\mathrm{x}$ & $\mathrm{o}$ & Com/Resp- & $\mathrm{o}$ & $\mathrm{x}$ & \\
\hline Carphone Warehouse & General Retailers & & $\mathrm{o}$ & $\mathrm{x}$ & $\mathrm{x}$ & $\mathrm{o}$ & Com/Resp- & $\mathrm{o}$ & $\mathrm{x}$ & \\
\hline Centrica & Gas, Water \& Utilities & & $\mathrm{o}$ & $\mathrm{x}$ & $\mathrm{x}$ & 0 & Com/Resp- & $\mathrm{o}$ & $\mathrm{x}$ & \\
\hline Hammerson & Real Estate Investm. Trusts & & $\mathrm{o}$ & $\mathrm{x}$ & $\mathrm{x}$ & 0 & Com/Resp- & $\mathrm{o}$ & $\mathrm{x}$ & \\
\hline Intercontinental Hotels & Travel \& Leisure & & $\mathrm{o}$ & $\mathrm{x}$ & $\mathrm{x}$ & 0 & Com/Resp- & o & $\mathrm{x}$ & \\
\hline Mondi & Forestry \& Paper & & $\mathrm{o}$ & $\mathrm{x}$ & $\mathrm{x}$ & 0 & Com/Resp- & o & $\mathrm{x}$ & \\
\hline Morrissons & Food/ Drug Retailers & & $\mathrm{o}$ & $\mathrm{x}$ & $\mathrm{x}$ & 0 & Com/Resp- & $\mathrm{o}$ & $\mathrm{x}$ & \\
\hline National Grid & Gas, Water \& Utilities & & $\mathrm{o}$ & $\mathrm{x}$ & $\mathrm{x}$ & 0 & Com/Resp- & o & $\mathrm{x}$ & \\
\hline Pearson & Media & & $\mathrm{o}$ & $\mathrm{x}$ & $\mathrm{x}$ & 0 & Com/Resp- & o & $\mathrm{x}$ & \\
\hline Sainsbury's & Food/ Drug Retailers & & $\mathrm{o}$ & $\mathrm{x}$ & $\mathrm{x}$ & 0 & Com/Resp- & o & $\mathrm{x}$ & \\
\hline Taylor Wimpey & Home Construct. & & $\mathrm{o}$ & $\mathrm{x}$ & $\mathrm{x}$ & 0 & Com/ Resp- & o & $\mathrm{x}$ & \\
\hline United Utilities & Gas, Water \& Utilities & & $\mathrm{o}$ & $\mathrm{x}$ & $\mathrm{x}$ & 0 & Com/Resp- & o & $\mathrm{x}$ & \\
\hline Vodafone & Mobile Telecommunications & & $\mathrm{o}$ & $\mathrm{x}$ & $\mathrm{x}$ & o & Com/Resp- & $\mathrm{o}$ & $\mathrm{x}$ & \\
\hline \multicolumn{11}{|c|}{ 4. Proactive Responsibility Business Models (Proactives) } \\
\hline Intu & Real Estate Investm. Trusts & & $\mathrm{o}$ & $\mathrm{x}$ & $\mathrm{x}$ & $\mathrm{o}$ & Com/Resp- & o & $\mathrm{x}$ & CR Progr. \\
\hline Kingfisher & General Retailers & & $\mathrm{o}$ & $\mathrm{x}$ & $\mathrm{x}$ & 0 & Com/Resp- & o & $\mathrm{x}$ & CR Progr. \\
\hline Marks \& Spencer (M\&S) & Food/ Drug Retailers & & o & $\mathrm{x}$ & $\mathrm{x}$ & o & Com/Resp- & $\mathrm{o}$ & $\mathrm{x}$ & CR Progr. \\
\hline Shire & Pharma \& Biotech & & $\mathrm{o}$ & $\mathrm{x}$ & $\mathrm{x}$ & o & Com/Resp- & $\mathrm{o}$ & $\mathrm{x}$ & CR Progr. \\
\hline Unilever & Consumer Goods & & $\mathrm{o}$ & $\mathrm{x}$ & $\mathrm{x}$ & o & Com/Resp- & $\mathrm{o}$ & $\mathrm{x}$ & CR Progr. \\
\hline Whitbread & Retail Hospitality & & $\mathrm{o}$ & $\mathrm{x}$ & $\mathrm{x}$ & o & Com/Resp- & $\mathrm{o}$ & $\mathrm{x}$ & CR Progr. \\
\hline \multicolumn{11}{|c|}{ No Business Model Artefact Included in Annual Report } \\
\hline Carnival & Travel \& Leisure & & $\mathrm{o}$ & $\mathrm{o}$ & 0 & $\mathrm{o}$ & Com/Resp+ & $\mathrm{o}$ & $\mathrm{o}$ & \\
\hline Randgold & Mining & & $\mathrm{o}$ & 0 & 0 & o & Com/Resp- & $\mathrm{o}$ & 0 & \\
\hline Reckitt Beckinser & Consumer Goods & & $\mathrm{o}$ & 0 & 0 & $\mathrm{o}$ & Com/Resp- & $\mathrm{o}$ & $\mathrm{o}$ & \\
\hline WPP & Media & & $\mathrm{o}$ & $\mathrm{o}$ & 0 & 0 & Com/Resp- & $\mathrm{o}$ & $\mathrm{o}$ & \\
\hline
\end{tabular}


Table A. 2 Responsibility patterns frequency

\begin{tabular}{|l|l|r|r|r|r|}
\hline & & Discretionary & Remedial & Reactive & Proactive \\
\hline 1 & $\begin{array}{l}\text { Total average number of } \\
\text { responsibility element mentions }\end{array}$ & $\mathbf{1 7 . 7 0 0}$ & $\mathbf{2 9 . 3 8 5}$ & $\mathbf{2 2 . 1 2 5}$ & 36.167 \\
\hline
\end{tabular}

\begin{tabular}{|l|l|r|r|r|r|}
\hline $\mathbf{2}$ & A. PROPOSITION & $\mathbf{3 . 1 0 0}$ & $\mathbf{5 . 4 2 3}$ & $\mathbf{5 . 0 0 0}$ & $\mathbf{7 . 0 0 0}$ \\
\hline $\mathbf{3}$ & $\mathbf{1 . ~ A s p i r a t i o n a l i t y ~}$ & $\mathbf{1 . 0 0 0}$ & $\mathbf{1 . 5 3 8}$ & $\mathbf{1 . 5 0 0}$ & 2.833 \\
\hline 4 & a. Company's social motivation & 0.200 & 0.423 & 0.438 & 1.167 \\
\hline 5 & b. Stakeholder choice & 0.200 & 0.308 & 0.250 & 0.167 \\
\hline 6 & c. Stakeholder interests & 0.600 & 0.808 & 0.813 & 1.500 \\
\hline $\mathbf{7}$ & $\mathbf{2 .}$ Calibration & $\mathbf{0 . 6 0 0}$ & $\mathbf{0 . 8 0 8}$ & $\mathbf{1 . 0 0 0}$ & $\mathbf{1 . 1 6 7}$ \\
\hline 8 & a. Amount of value & 0.600 & 0.538 & 0.813 & 0.833 \\
\hline 9 & b. Balancing value & 0.000 & 0.269 & 0.188 & 0.333 \\
\hline $\mathbf{1 0}$ & 3. Elements of proposition & $\mathbf{1 . 5 0 0}$ & 3.077 & $\mathbf{2 . 5 0 0}$ & $\mathbf{3 . 0 0 0}$ \\
\hline 11 & a. Variety of beneficiaries & 1.000 & 2.000 & 1.500 & 1.500 \\
\hline 12 & b. Products and services & 0.300 & 0.462 & 0.563 & 0.833 \\
\hline 13 & c. Types of value & 0.200 & 0.615 & 0.438 & 0.667 \\
\hline
\end{tabular}

\begin{tabular}{|l|l|r|r|r|r|}
\hline $\mathbf{1 4}$ & B. CREATION & $\mathbf{5 . 5 0 0}$ & $\mathbf{7 . 1 5 4}$ & $\mathbf{4 . 3 1 3}$ & $\mathbf{7 . 6 6 7}$ \\
\hline $\mathbf{1 5}$ & $\mathbf{1 .}$ Operationality & $\mathbf{1 . 3 0 0}$ & $\mathbf{2 . 2 3 1}$ & $\mathbf{1 . 1 2 5}$ & $\mathbf{1 . 0 0 0}$ \\
\hline 16 & a. Responsible operations & 0.400 & 0.885 & 0.438 & 0.333 \\
\hline 17 & b. Eco)Efficiency & 0.400 & 0.423 & 0.250 & 0.333 \\
\hline 18 & c. Social issues in operations & 0.500 & 0.923 & 0.438 & 0.333 \\
\hline $\mathbf{1 9}$ & $\mathbf{2 .}$ Decisions and actions & $\mathbf{1 . 2 0 0}$ & $\mathbf{1 . 5 3 8}$ & $\mathbf{1 . 4 3 8}$ & $\mathbf{3 . 1 6 7}$ \\
\hline 20 & a. 'Good' business approach & 0.300 & 0.385 & 0.625 & 1.667 \\
\hline 21 & b. Responsible decision making & 0.000 & 0.308 & 0.250 & 1.000 \\
\hline 22 & c. Responsible behavior & 0.900 & 0.846 & 0.563 & 0.500 \\
\hline $\mathbf{2 3}$ & 3. Integrating responsibility & $\mathbf{1 . 3 0 0}$ & $\mathbf{0 . 3 8 5}$ & $\mathbf{0 . 4 3 8}$ & $\mathbf{0 . 8 3 3}$ \\
\hline 24 & a. Integrated in culture & 0.600 & 0.231 & 0.188 & 0.333 \\
\hline 25 & b. Integrated across business & 0.700 & 0.154 & 0.250 & 0.500 \\
\hline $\mathbf{2 6}$ & 4. Human actors & $\mathbf{0 . 8 0 0}$ & 1.346 & $\mathbf{0 . 6 8 8}$ & $\mathbf{0 . 6 6 7}$ \\
\hline 27 & a. Responsible workplace & 0.500 & 0.577 & 0.250 & 0.333 \\
\hline 28 & b. Managerial responsibility & 0.000 & 0.346 & 0.250 & 0.000 \\
\hline 29 & c. Values & 0.300 & 0.423 & 0.188 & 0.333 \\
\hline $\mathbf{3 0}$ & $\mathbf{5 . ~ S t r u c t u r e s}$ & $\mathbf{0 . 9 0 0}$ & $\mathbf{1 . 6 5 4}$ & $\mathbf{0 . 6 2 5}$ & $\mathbf{2 . 0 0 0}$ \\
\hline 31 & a. Governance of responsibility & 0.500 & 0.615 & 0.188 & 0.167 \\
\hline 32 & b. Organizational (infra)structure & 0.100 & 0.308 & 0.375 & 0.167 \\
\hline 33 & c. Resources & 0.200 & 0.308 & 0.063 & 0.667 \\
\hline 34 & d. Corporate responsibility programme & 0.100 & 0.423 & 0.000 & 1.000 \\
\hline
\end{tabular}

\begin{tabular}{|r|l|r|r|r|r|}
\hline $\mathbf{3 5}$ & C. EXCHANGE & $\mathbf{5 . 2 0 0}$ & $\mathbf{1 0 . 2 3 1}$ & $\mathbf{7 . 8 1 3}$ & $\mathbf{8 . 8 3 3}$ \\
\hline $\mathbf{3 6}$ & 1. Relationality & $\mathbf{1 . 2 0 0}$ & $\mathbf{2 . 2 6 9}$ & $\mathbf{1 . 3 1 3}$ & $\mathbf{2 . 3 3 3}$ \\
\hline 37 & a. Relationships & 0.300 & 0.462 & 0.188 & 0.500 \\
\hline 38 & b. Relational qualities & 0.400 & 1.115 & 0.625 & 0.667 \\
\hline 39 & c. Relational hubs & 0.200 & 0.462 & 0.313 & 0.833 \\
\hline 40 & d. Culture & 0.300 & 0.077 & 0.125 & 0.167 \\
\hline 41 & e. Reputation and brand & 0.000 & 0.154 & 0.063 & 0.167 \\
\hline $\mathbf{4 2}$ & 2. Modes of exchange & $\mathbf{2 . 1 0 0}$ & 4.692 & $\mathbf{4 . 2 5 0}$ & $\mathbf{4 . 0 0 0}$ \\
\hline 43 & a. Making connections & 0.300 & 0.577 & 0.500 & 0.167 \\
\hline 44 & b. Dialogue & 0.200 & 0.538 & 0.375 & 0.000 \\
\hline 45 & c. Providing benefits & 0.300 & 0.731 & 1.063 & 0.667 \\
\hline 46 & d. Developing and enabling & 0.400 & 0.731 & 0.563 & 0.667 \\
\hline 47 & e. Engagement & 0.300 & 0.231 & 0.438 & 0.333 \\
\hline
\end{tabular}




\begin{tabular}{|l|l|l|l|l|l|}
48 & f. Instrumental relationships & 0.200 & 0.308 & 0.125 & 0.333 \\
\hline 49 & g. Cocreation and partnership & 0.300 & 0.731 & 0.313 & 1.167 \\
\hline 50 & h. Material exchange & 0.100 & 0.462 & 0.563 & 0.667 \\
\hline 51 & i. Contractual-transactional relation & 0.000 & 0.385 & 0.313 & 0.000 \\
\hline $\mathbf{5 2}$ & 3. Exchange counterparts & $\mathbf{1 . 9 0 0}$ & 3.269 & $\mathbf{2 . 2 5 0}$ & $\mathbf{2 . 5 0 0}$ \\
\hline 53 & a. Stakeholders & 0.100 & 0.462 & 0.063 & 0.000 \\
\hline 54 & b. Community & 0.400 & 0.462 & 0.500 & 0.333 \\
\hline 55 & c. Customers & 0.200 & 0.385 & 0.438 & 0.500 \\
\hline 56 & d. Employees & 0.200 & 0.308 & 0.188 & 0.167 \\
\hline 57 & e. Government and regulators & 0.200 & 0.615 & 0.063 & 0.000 \\
\hline 58 & f. Shareholders & 0.100 & 0.077 & 0.188 & 0.000 \\
\hline 59 & g. Society & 0.000 & 0.115 & 0.125 & 0.167 \\
\hline 60 & h. Suppliers and partners & 0.600 & 0.538 & 0.500 & 1.000 \\
\hline 61 & i. (Local) environment & 0.100 & 0.269 & 0.188 & 0.333 \\
\hline
\end{tabular}

\begin{tabular}{|r|l|r|r|r|r|}
\hline $\mathbf{6 2}$ & D. CAPTURE & $\mathbf{3 . 9 0 0}$ & $\mathbf{6 . 5 7 7}$ & $\mathbf{5 . 0 0 0}$ & $\mathbf{1 2 . 6 6 7}$ \\
\hline $\mathbf{6 3}$ & $\mathbf{1 .}$ Consequentiality & $\mathbf{1 . 1 0 0}$ & $\mathbf{1 . 6 5 4}$ & $\mathbf{1 . 3 7 5}$ & 2.667 \\
\hline 64 & a. Multiple bottom lines & 0.000 & 0.231 & 0.125 & 0.167 \\
\hline 65 & b. Forms of capture & 0.800 & 1.115 & 0.938 & 1.500 \\
\hline 66 & c. Impact reduction & 0.300 & 0.308 & 0.313 & 1.000 \\
\hline $\mathbf{6 7}$ & $\mathbf{2 .}$ Measurement and evaluation & $\mathbf{1 . 7 0 0}$ & $\mathbf{1 . 6 5 4}$ & $\mathbf{1 . 2 5 0}$ & 3.500 \\
\hline 68 & a. Accounting and accountability & 0.000 & 0.231 & 0.000 & 0.333 \\
\hline 69 & b. Indicators and metrics & 0.400 & 0.615 & 0.375 & 1.333 \\
\hline 70 & c. Interpretation and standardization & 0.600 & 0.115 & 0.313 & 0.333 \\
\hline 71 & d. Performance and success & 0.400 & 0.385 & 0.313 & 0.667 \\
\hline 72 & e. Economic factors & 0.300 & 0.308 & 0.250 & 0.833 \\
\hline $\mathbf{7 3}$ & 3. Growth and development & $\mathbf{0 . 4 0 0}$ & $\mathbf{1 . 8 0 8}$ & $\mathbf{1 . 3 1 3}$ & 2.333 \\
\hline 74 & a. Optimization of Impact & 0.100 & 0.154 & 0.188 & 0.500 \\
\hline 75 & b. (Re)Distribution of value & 0.200 & 0.615 & 0.625 & 0.667 \\
\hline 76 & c. Social investment \& funding & 0.100 & 0.423 & 0.375 & 0.500 \\
\hline 77 & d. Company reproduction & 0.000 & 0.615 & 0.125 & 0.667 \\
\hline $\mathbf{7 8}$ & 4. Outcomes & $\mathbf{0 . 7 0 0}$ & $\mathbf{1 . 4 6 2}$ & $\mathbf{1 . 0 6 3}$ & 4.167 \\
\hline 79 & a. Impact & 0.400 & 0.500 & 0.313 & 1.333 \\
\hline 80 & b. Scale & 0.100 & 0.231 & 0.313 & 2.000 \\
\hline 81 & c. Timing & 0.200 & 0.731 & 0.438 & 0.833 \\
\hline
\end{tabular}




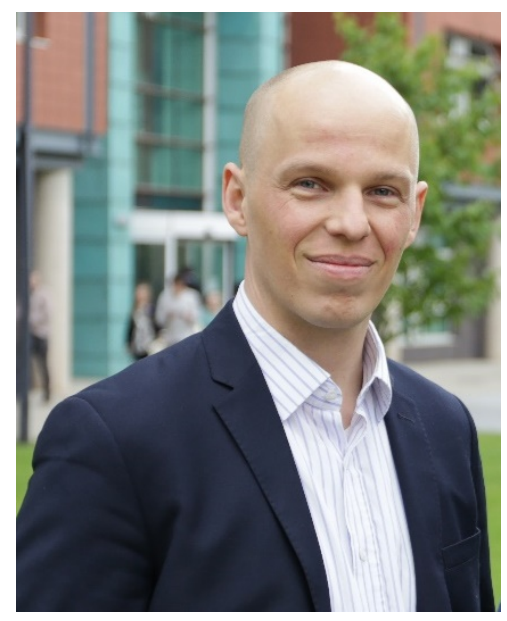

Oliver Laasch is Assistant Professor of Strategy at the University of Nottingham Ningbo China, a Governing Responsible Business research fellow at Copenhagen Business School, and a permanent visiting professor at the University of Tübingen. He studies alternative business models and responsible management learning. Oliver has published in Academy of Management Learning and Education, Journal of Management Education, Long Range Planning, Journal of Business Ethics, and Organization and Environment, among others. He serves on the editorial board of AMLE and has edited special issues for JBE and JME.

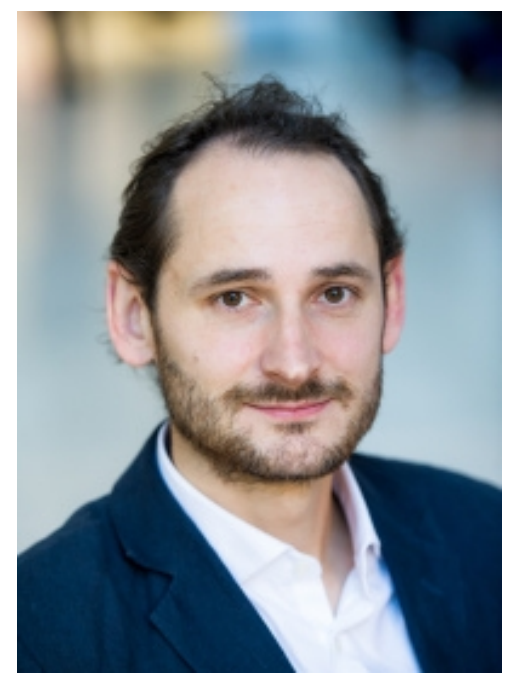

Jonatan Pinkse is Professor of Strategy, Innovation and Entrepreneurship at the Alliance Manchester Business School of the University of Manchester and Executive Director of the Manchester Institute of Innovation Research (MIOIR). His research interests focus on corporate sustainability, business responses to climate change, and innovation in renewable energy. Jonatan has published widely on these and other topics in academic and practitioner-oriented journals, including Academy of Management Review, Journal of International Business Studies, Research Policy, Organization Studies, and California Management Review, among others. 